\title{
"تطوير إدارات التخطيط العمرانى بالمحافظات فى ضوء التحول الرقمى" Developing Urban Planning Departments in Governorates in the light of Digital Transformation
}

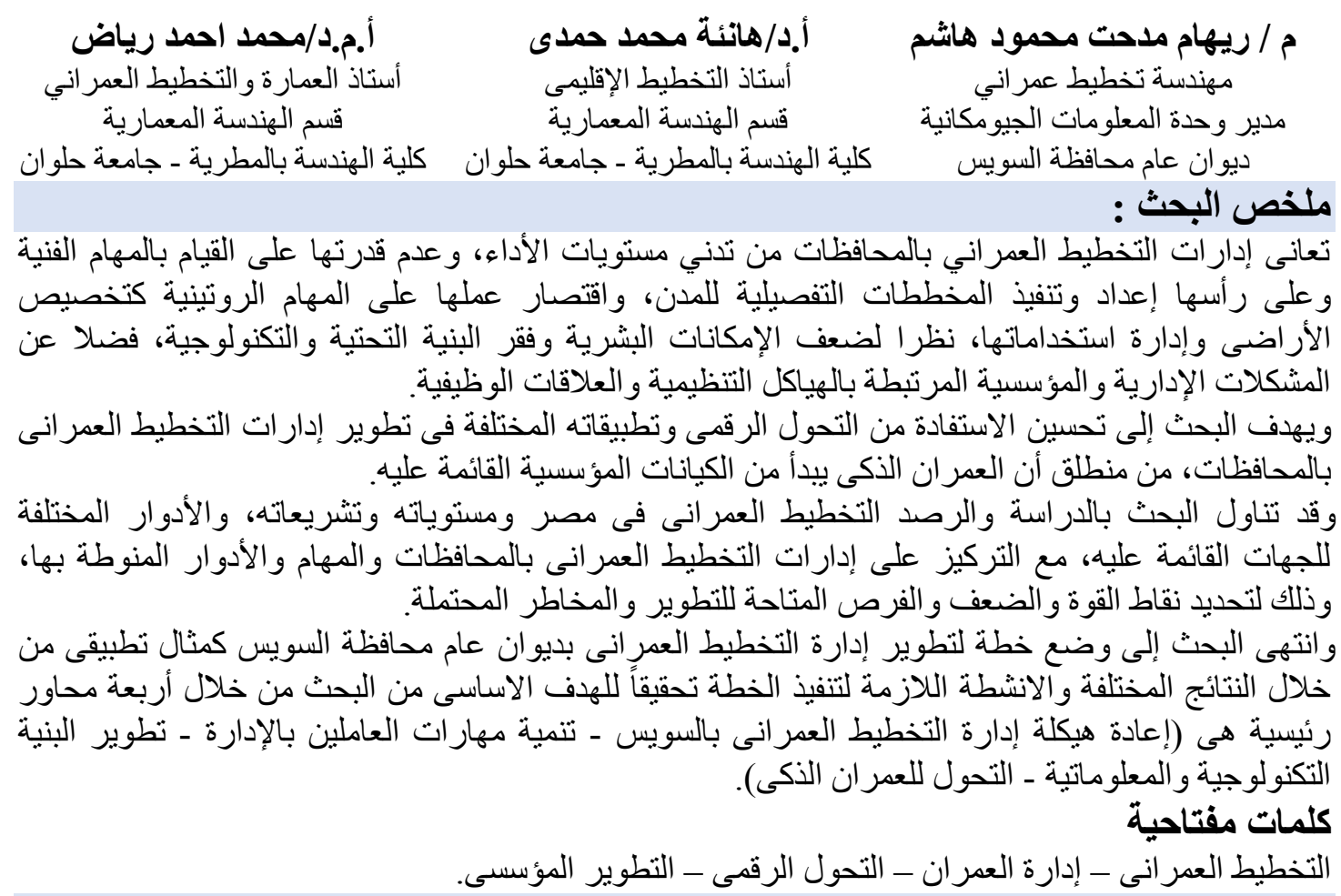

Urban planning departments in the governorates suffer from low levels of performance, and their inability to carry out technical tasks, foremost of which is preparing and implementing city detailed plans, and limiting their work to routine tasks such as allocating land and managing its uses, due to weak human capabilities and poor infrastructure and technology, as well as administrative and institutional problems associated with organizational structures and functional relationships.

The research aims to improve the utilization of digital transformation and its various applications in the development of urban planning departments in the governorates, on the grounds that smart urbanization starts with the institutional entities based on it. The research dealt with study and monitoring of urban planning in Egypt, its levels and legislation, and the different roles of the authorities in charge of it, with a focus on urban planning departments in the governorates and the tasks and roles assigned to them, in order to identify strengths and weaknesses, opportunities for development and potential risks.

The research ended with the plan for the development of the Urban Planning Department in the Suez Governorate as an applied example through the various results and activities necessary to implement the plan to achieve the main objective of the research through four main axes (Restructuring the Urban Planning Department in Suez - Developing the skills of employees - Developing the technological and information infrastructure - Transforming into smart urbanization).

\section{Keywords}

Urban planning - urban management - digital transformation - institutional development. 
مقدمة

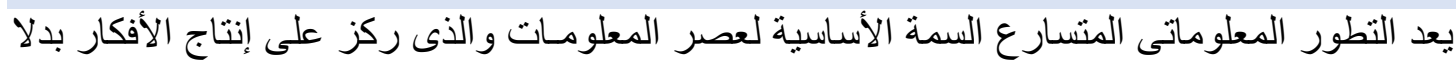

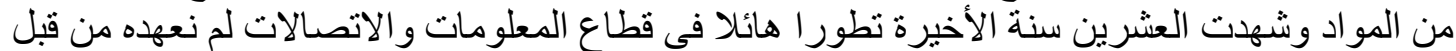

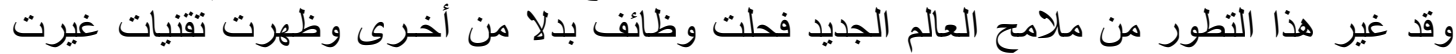

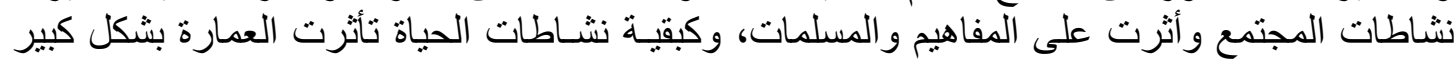

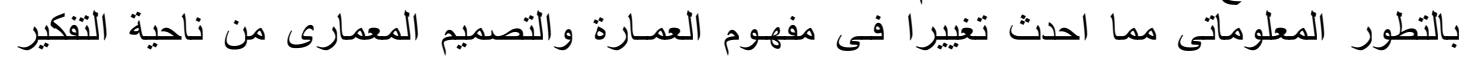

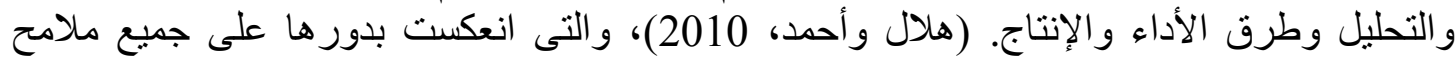

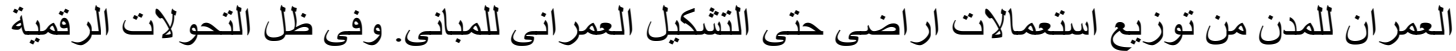

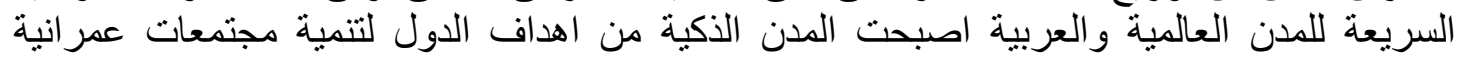

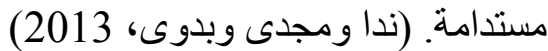

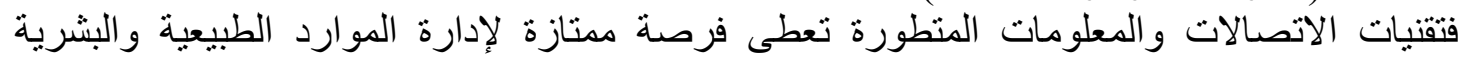

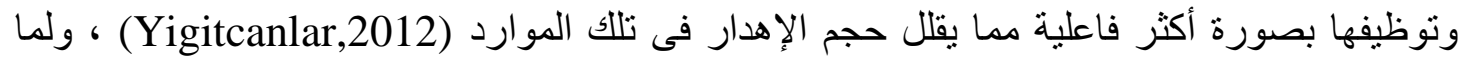

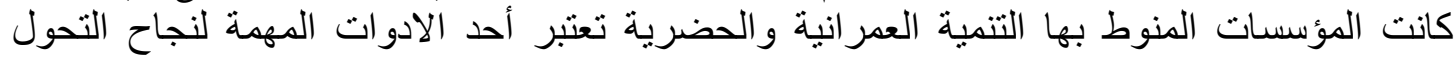

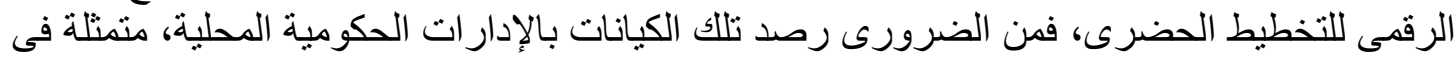

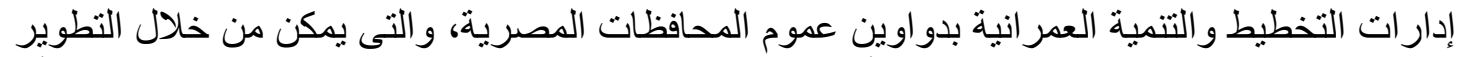

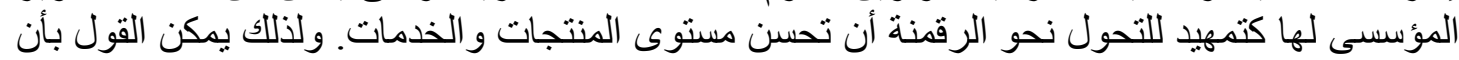

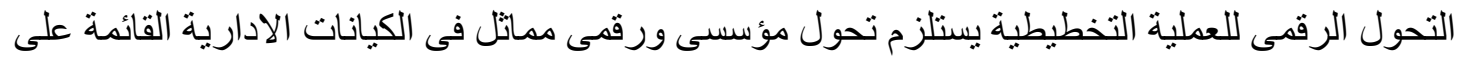
العملية التخطيطية.

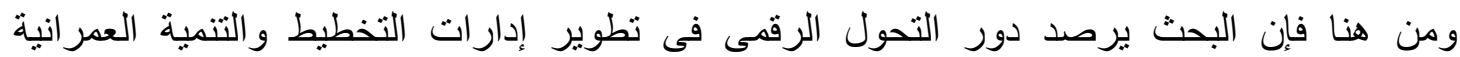

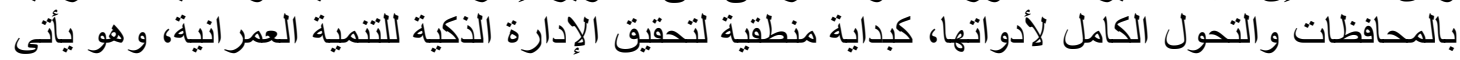

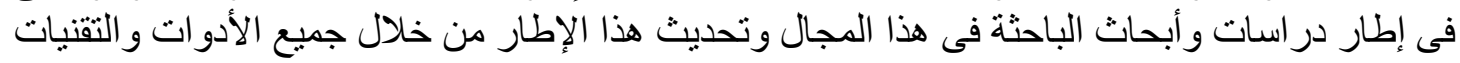

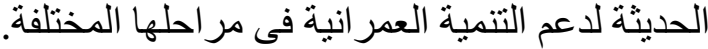

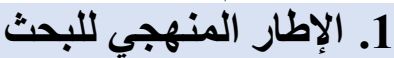
ويتناول الإطلار المنهجى للبحث الإنكالية البحثية، وفرضية البحث، وأهميته، والمنهج الفكرى المتبع

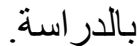

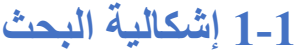

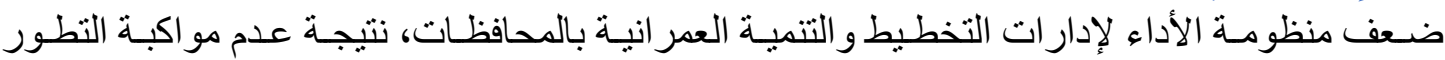

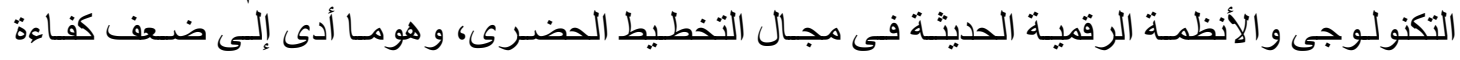
إستغلال الموارد و إهدار ها، و إنخفاض مستوى الخدمات الخدات و المنتجات المقدمة.

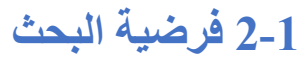
تطوير إدارات التخطيط العمرانى بالمحافظات من خلال التطوير المؤسسى الإدارى ورفع القدرات

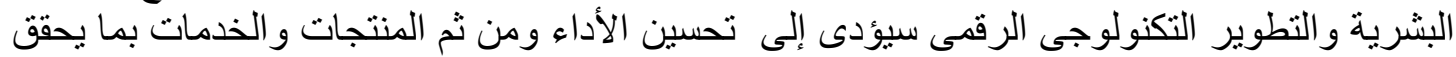

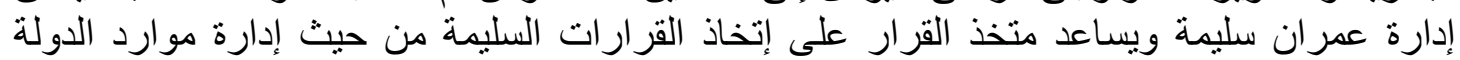
و المحافظة عليها وتحسين إستغلالها.

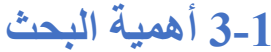

يسهم فى وضع إطار عام لتطوير أداء إدارات التخطيط العمر انى بالمحافظات وهو ما يؤدى إلى إلى تحسين

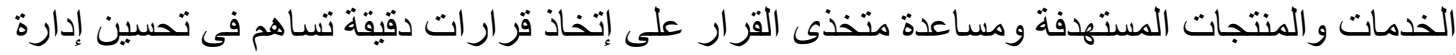
أر اضى وموارد الدولة و الحد من الإهدار.

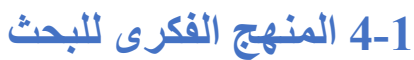

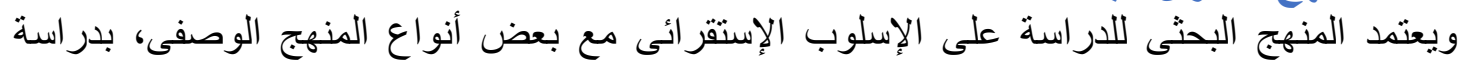

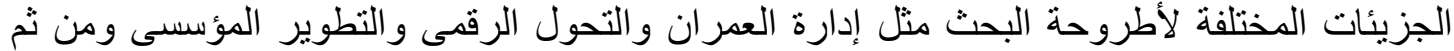

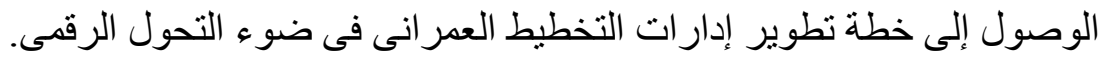




\section{2 الإطار النظرى للبحث}

ويتناول الإطار النظرى التخطيط العمرانى، ومهام إدارات التخطيط والتتمية العمرانية بالمحافظات، والتحول

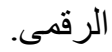

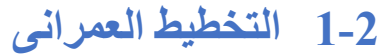

\section{1-1-2 تعريف التخطيط العمرانى التى التئ}

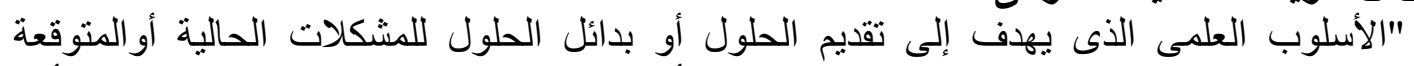

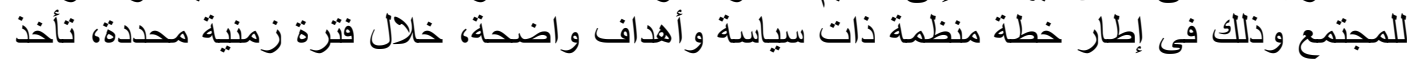

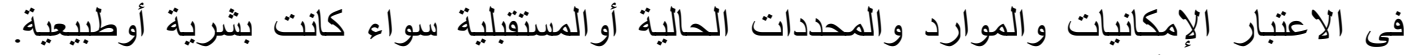

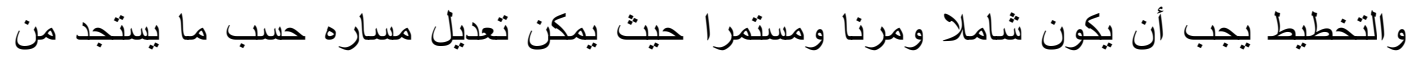

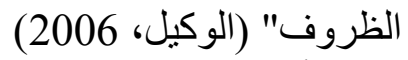

\section{2-1-2}

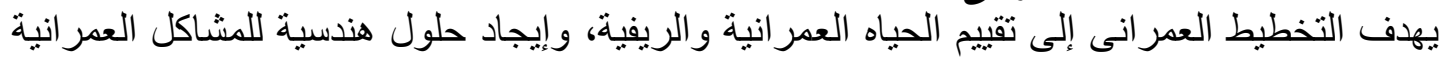

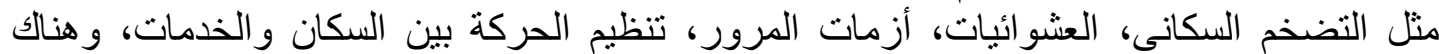

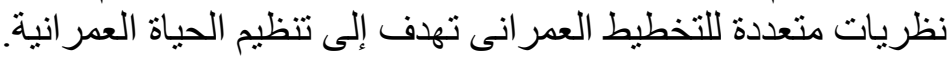

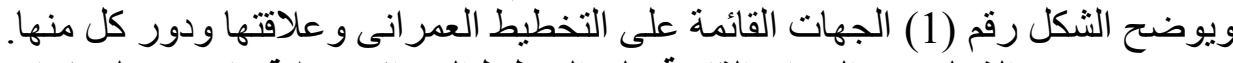
الثكل (1) الجهات القائمة على التخطيط العمرانى وعلاقتها ودور كل منها

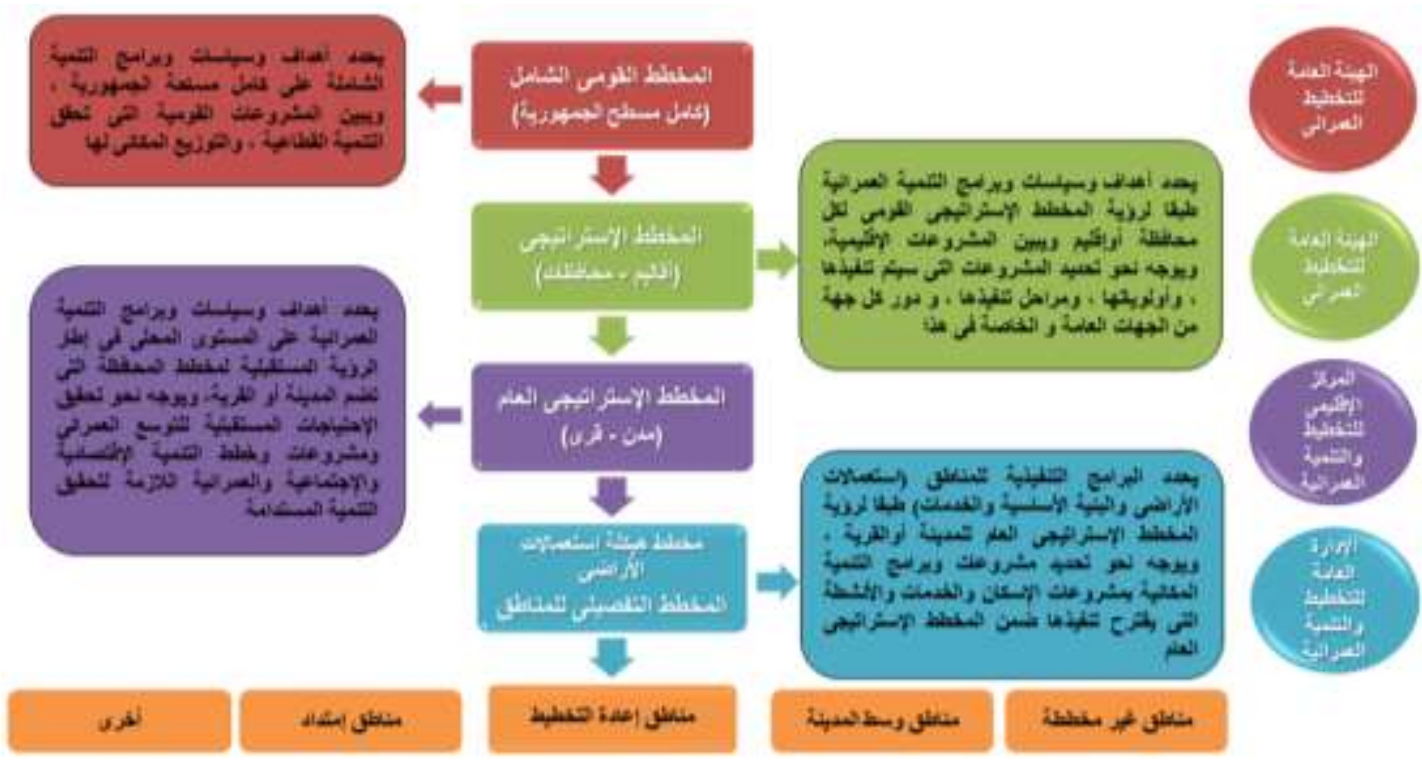

$$
\text { المصدر : إعداد الباحث }
$$

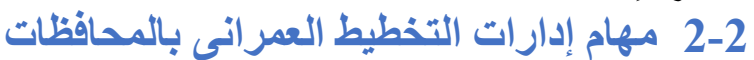

1-2-2 م مهام إدارات التخطيط العمراني حسب نص قانون البناء الموحد 119 لسنة 2008

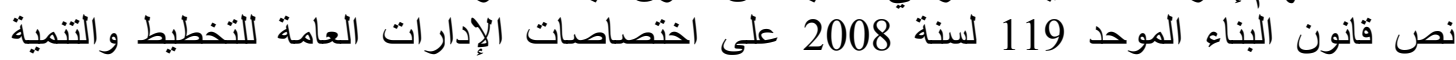

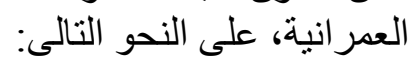

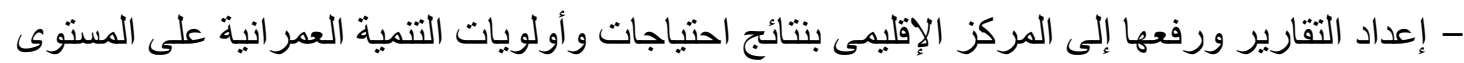

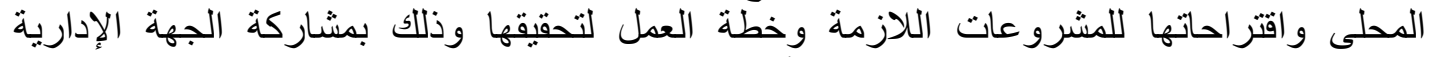

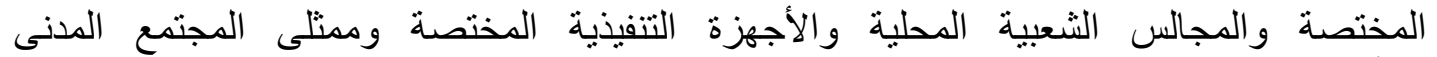

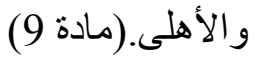

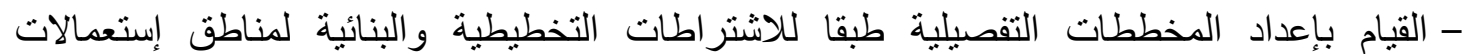

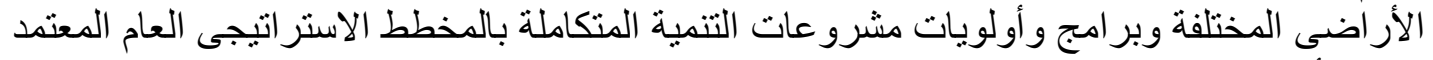
(مادة 15) (مالة (15)

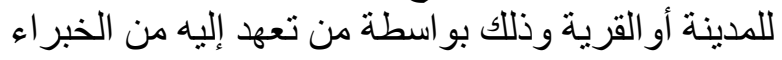

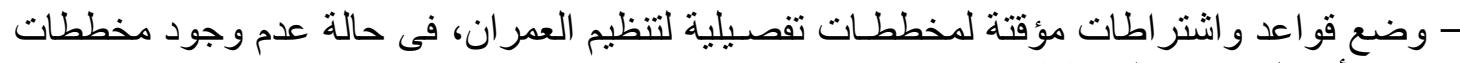
عامة أو قبل اعتماد المخططات الاستر اتيجية. (مادة 15) 
- وضع اشتراطات بنائية مؤقتة للمنـاطق القائمة التى لم تحدد لها اشتراطات بنائية وعلى الأخص إنص

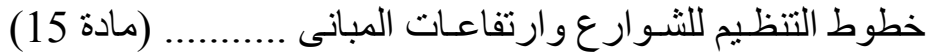

- يصدر المحافظ المختص بناء على عرض الإدارة العامة للتخطيط والتنمية العمرانية قراراً باعنماد (مادة 16) (لمبران)

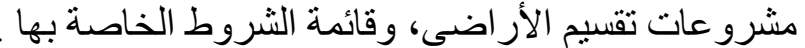

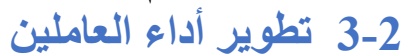

يعتبر تطبيق المنظمة لأفضل الممارسات و الأساليب الحديثة فى أداء مهام العاملين بهدف إثباع رغبات عملائها.

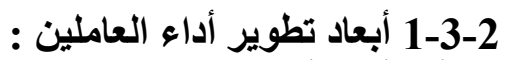

من أهم أبعاد أداء العاملين التى يجب أبعاء التركيز عليها لتطوير أدائهم الوظيفى ما يلى: (Schmidt, 2010)

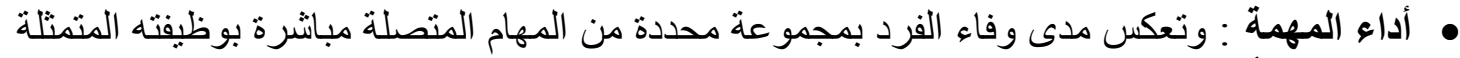
فى كمية الأداء_ الإتقان_ الكفاءة- الوقت المحدد للإنجاز ، بالإضافة إلى الإلى الإلمام بكل جو انب الوظيفة.

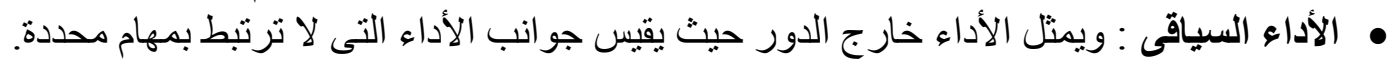

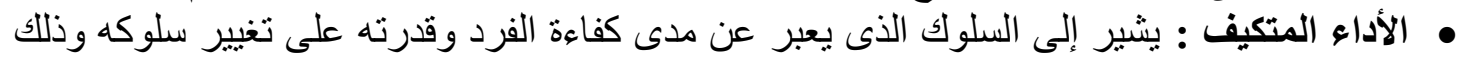
لمقابلة متطلبات التغيير فى البيئة الداخلية والخارجية للمنظمة التى يعمل بهاء التيرة

2-3-2

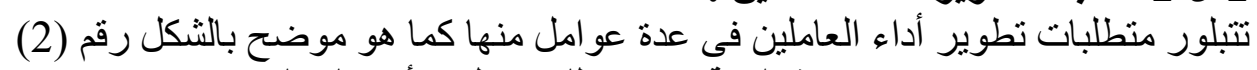
شكل رقم (2) متطلبات تطوير أداء العاملين

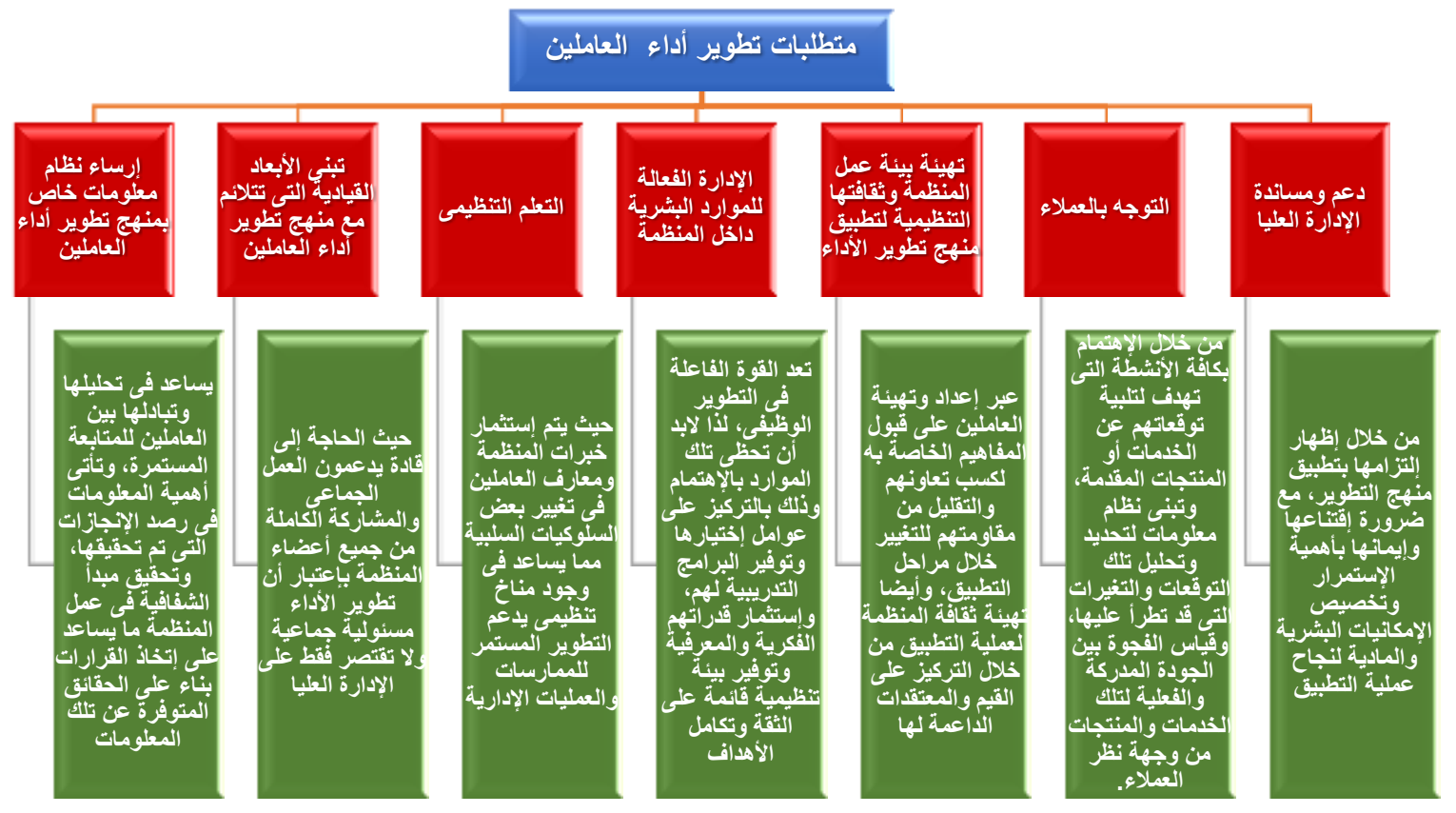

المصدر : إعداد الباحث عن مرجع (حماد، 2020)

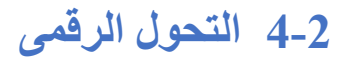

إتجهت مصر إلى مبادرة بناء وإدارة وتثغيل الأجهزة الحكومية والبنية التحتية والأعمال لتطبيق

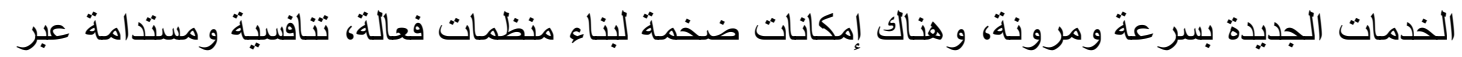
التحول الرقمى، والذى يسعى لتحقيق تغيير جذرى فى في خدمات المواطنين فى المجالات فئات المختلفة،

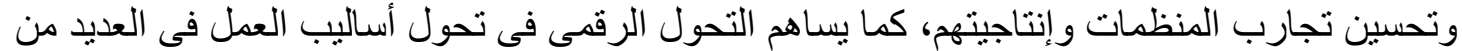

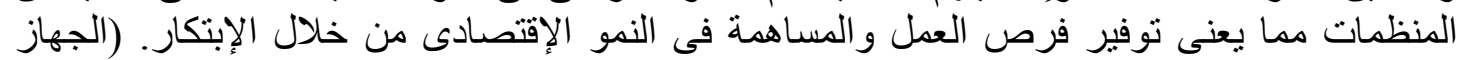

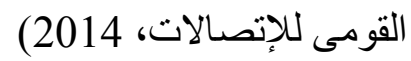


1-4-2 1-2 مفهوم التحول الرقمى

هناك العديد من التعريفات للتحول التحول الرقمى، تم إيجاز بعضها فيما يلى:-

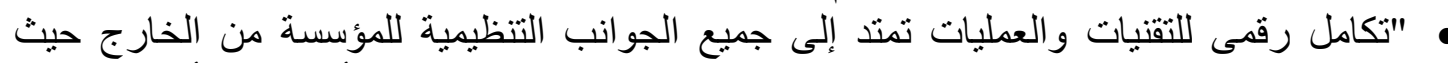

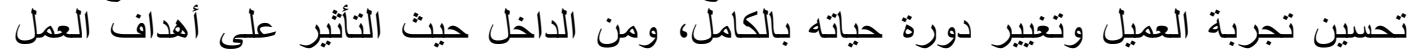

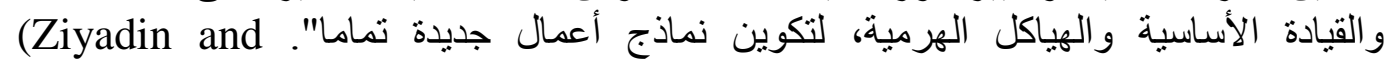

.Suieubayeva, 2020)

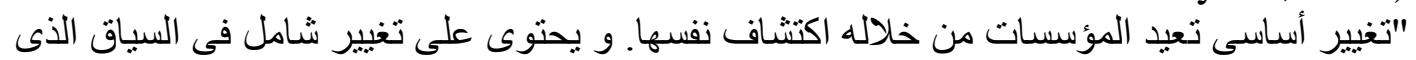

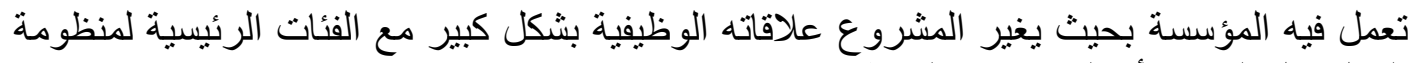
العمل منل العملاء أو الموردين و الموظفئ بونين" (David and Thomas, 2018).

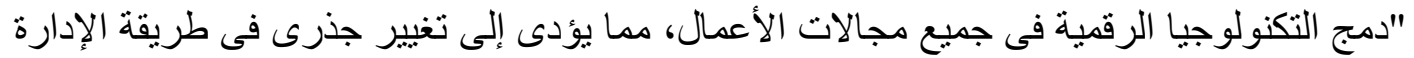

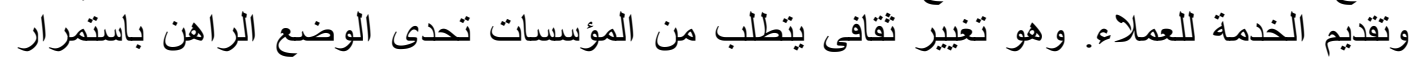

و التجربة" (Enterprisers Project, 2020).

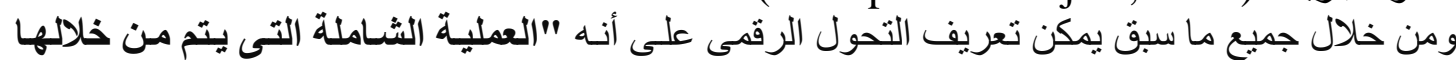

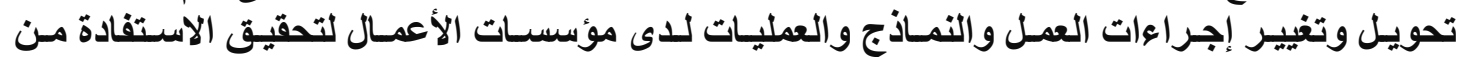

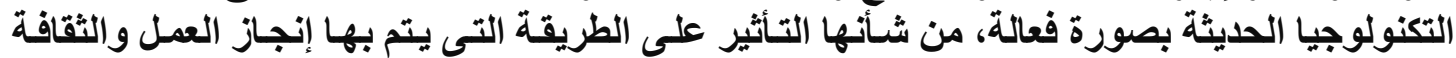

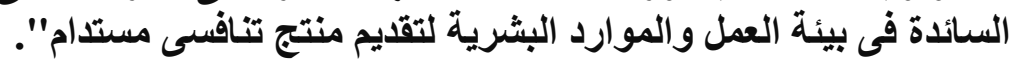

2-4-2

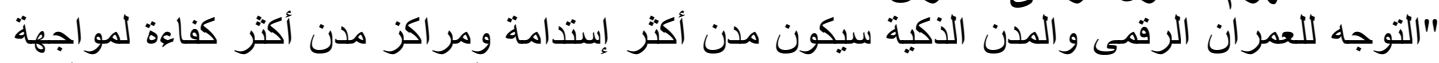

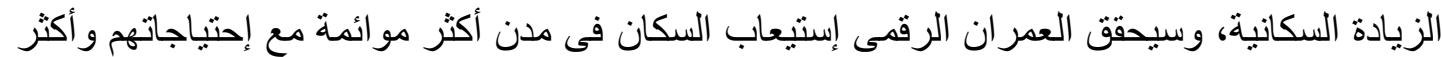

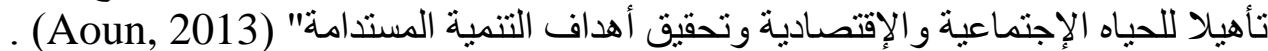

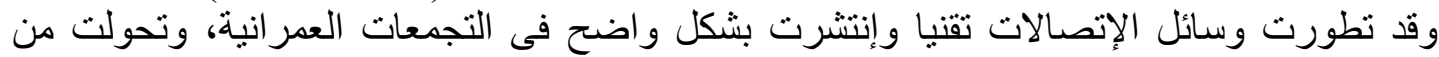

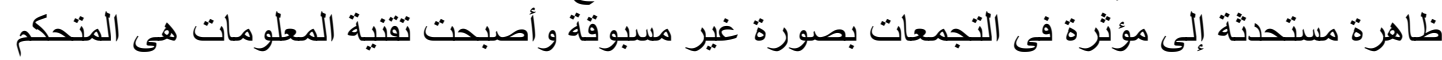

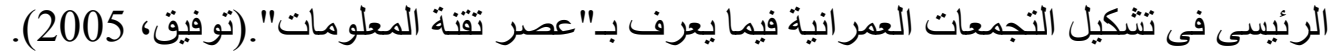
الثكل رقم (3) فوائد التحول الرقمى ويوضح الثكل رقم (3) فو ائد التحول الرئ الرقمى.

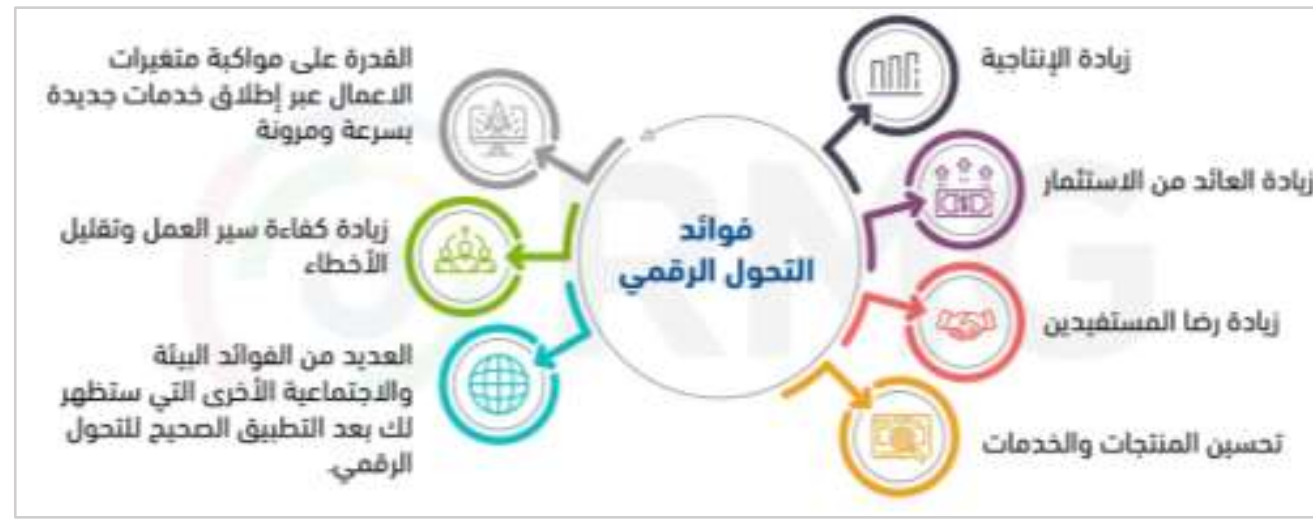

https://www.rmg-sa.com/\%D8\%A7\%D9\%84\%D8\%AA\%D8\%AD\%D9\%88\%D9\%84-

$\% \mathrm{D} 8 \% \mathrm{~A} 7 \% \mathrm{D} 9 \% 84 \% \mathrm{D} 8 \% \mathrm{~B} 1 \% \mathrm{D} 9 \% 82 \% \mathrm{D} 9 \% 85 \% \mathrm{D} 9 \% 8 \mathrm{~A}-$

dt/\%D8\%A7\%D9\%84\%D8\%AE\%D8\%AF\%D9\%85\%D8\%A7\%D8\%AA-

\%D8\%A7\%D9\%84\%D8\%A7\%D8\%B3\%D8\%AA\%D8\%B4\%D8\%A7\%D8\%B1\%D9\%8A\%D8\%A9-\%D9\%81\%D9\%8A-

\%D8\%A7\%D9\%84\%D8\%AA\%D8\%AD\%D9\%88\%D9\%84-\%D8\%A7\%D9\%84\%D8\%B1\%D9\%82\%D9\%85\%D9\%8A/

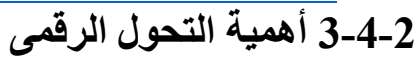

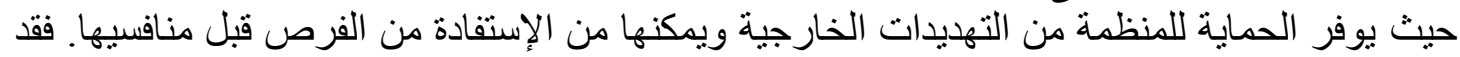

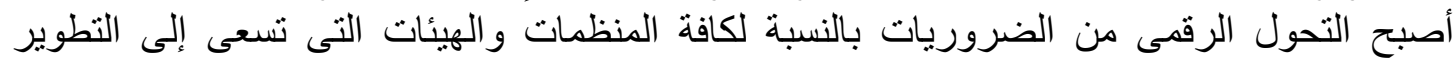

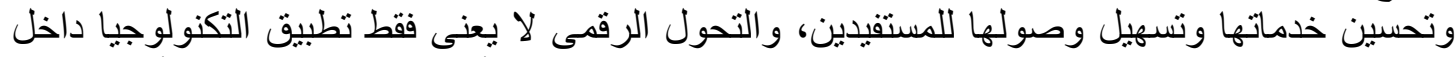

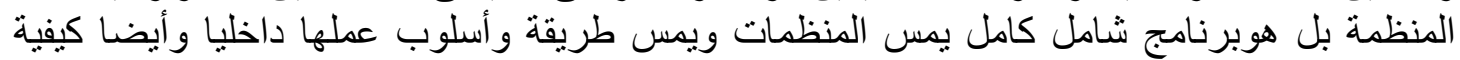
تقديم الخدمات للجمهور المستهدف لجعل الخدمات تتم بشكل أسهل وأسرع. (شاهين، 2013) 


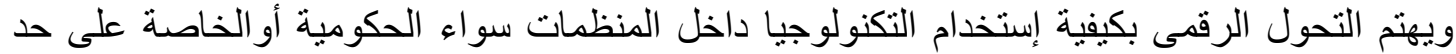

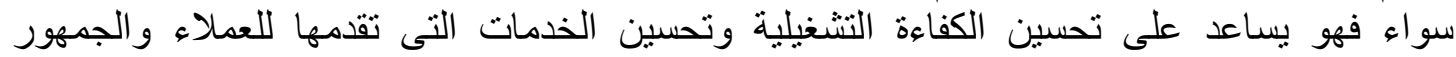

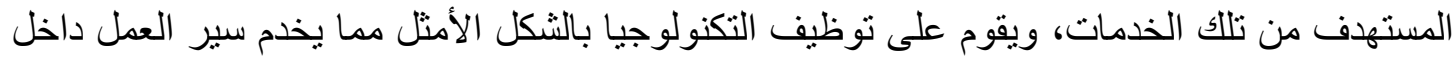
المنظمة فى كافة أقسامها، وأيضا فى تعاملها مع العملاء لتحسين الخدمات وتسهيل الحصول علئ اليها مما

يضمن توفير الوقت و الجهد في آن واحد. (Frida , 2020)

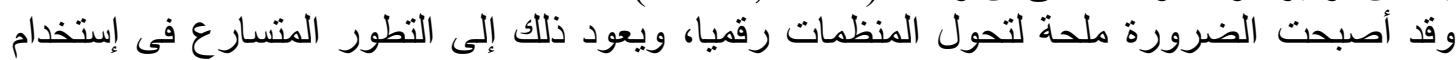

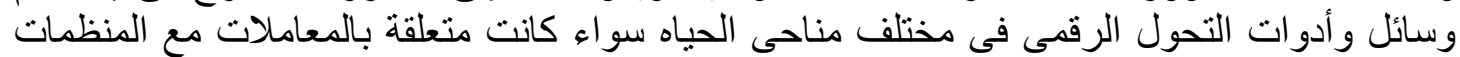

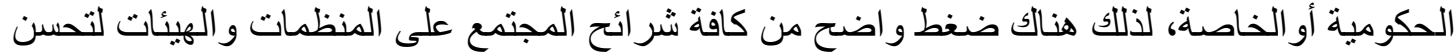

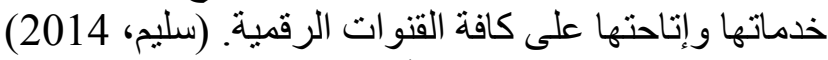

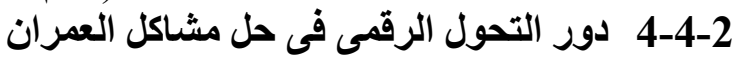

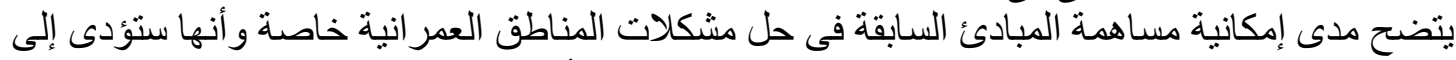

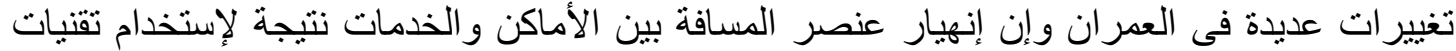

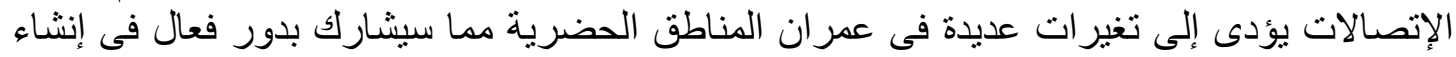

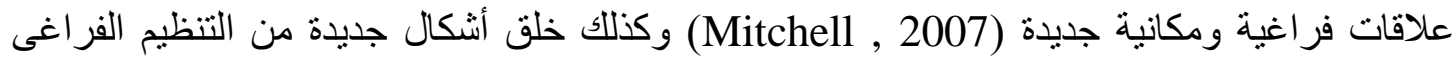

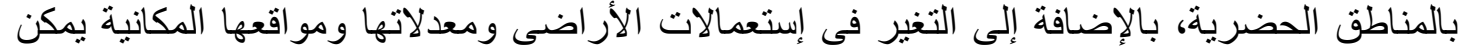

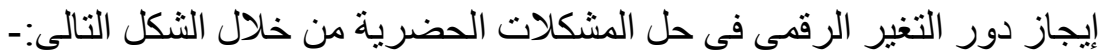

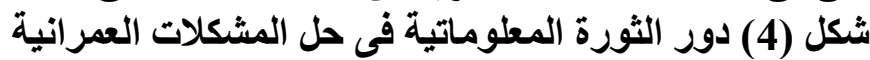

\begin{tabular}{|c|c|c|c|c|c|}
\hline \multicolumn{6}{|c|}{ المشكلات العمر ائية } \\
\hline 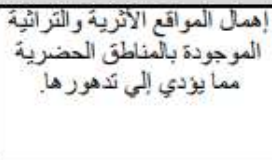 & 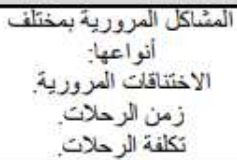 & 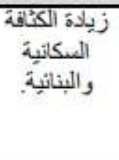 & الاسنَعمالات & 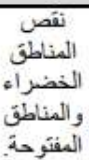 & تونقات \\
\hline
\end{tabular}

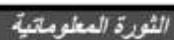

\begin{tabular}{|c|c|c|c|c|}
\hline \multicolumn{5}{|c|}{ الحل المتوقع من نتيجة استخدام تنتيات الثورة المعلوماتية } \\
\hline 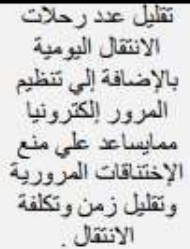 & 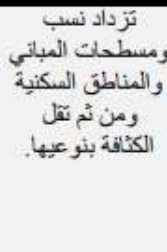 & 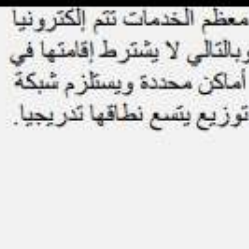 & 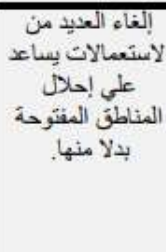 & 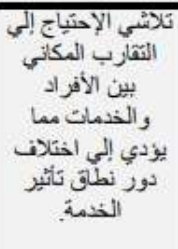 \\
\hline
\end{tabular}

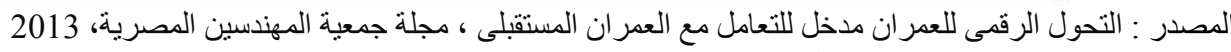

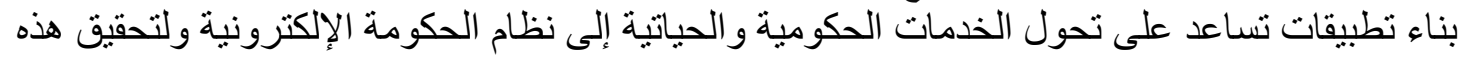
الأهداف يمكن الإستفادة من إستراتيجية قطاع الإتصالات وتكنولوجيا المعلومات "مصر تركز على ثلاث محاور رئيسية :

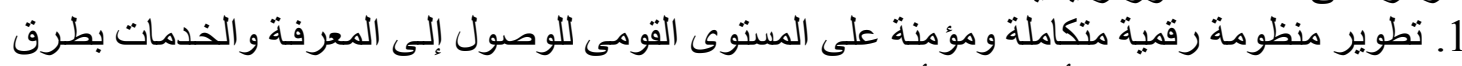

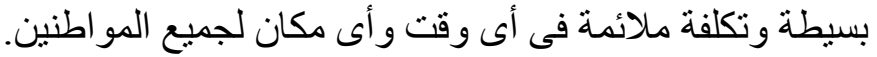

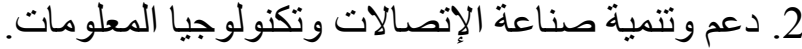

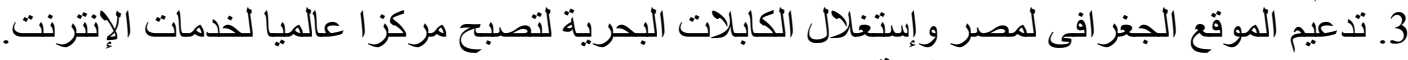
0-4-2

• الحوسبة السحابية : حيث يمكن الدخول لإمولة للخدمات الحكومية من مختلف الأماكن و الأجهزة. ه الهوية الرقمية : للتخلص من التحايل وانتحال الثخصية حيث يصبح لكل مستخدم هوية رقمية تميزه

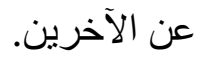
• التكامل البينى بين الأنظمة الحكومية : حيث يستفبد كل نظام من الترابط مع الأنظمة الأخرى، بما

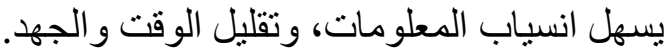

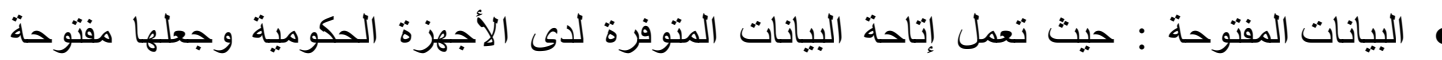
المصدر على الاستفادة منها فى التحول الرقمى. 


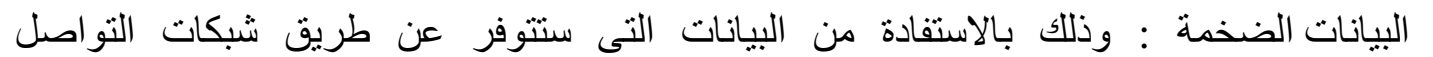

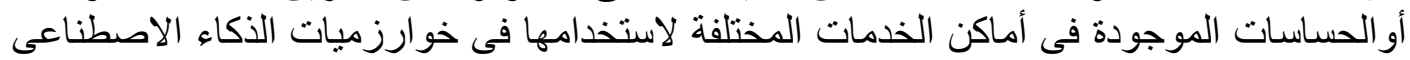
للتحول للخدمات الذكية.

تخطيط موارد المؤسسات (ERP) : هو تطبيق يستخدم قاعدة بيانات مركزية تتلقى معلومات من

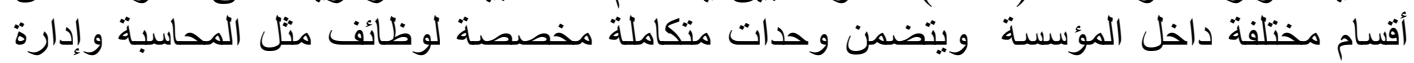
المخزون و إدارة علاقات العملاء، ويمنح نظام تخطيط موارد المؤستسات (ERP) المؤسسات مكانًا

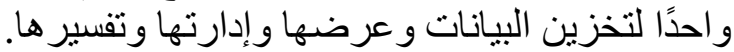

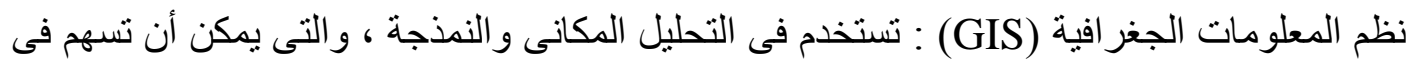

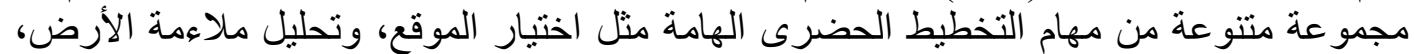

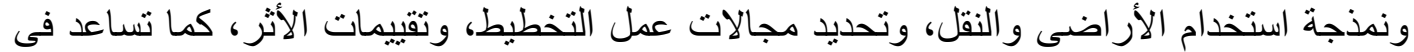

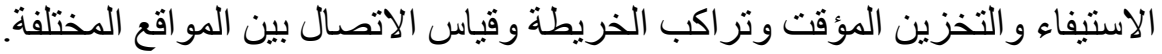

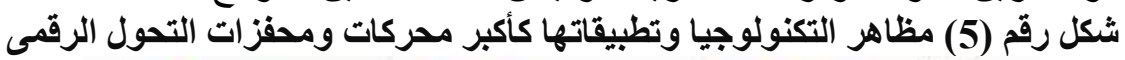

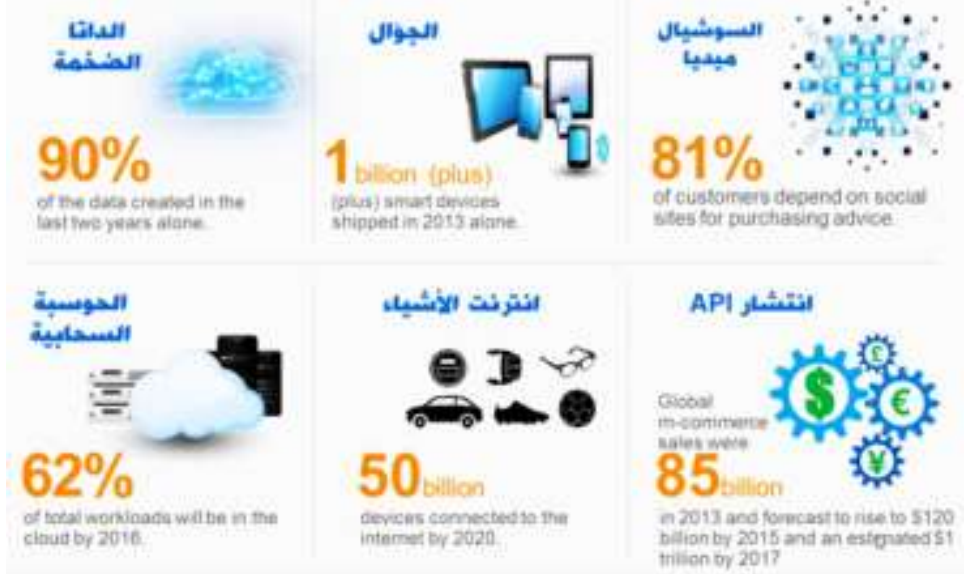

http://www.egovconcepts.com/ المصدر :

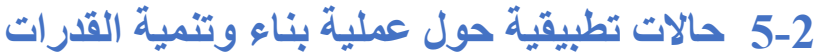

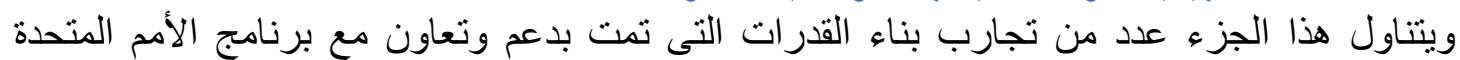

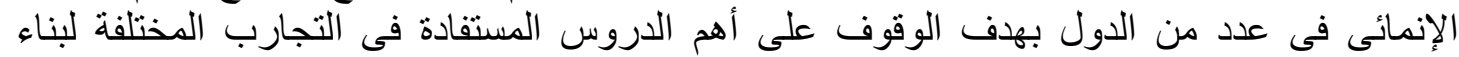

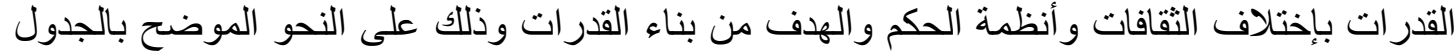

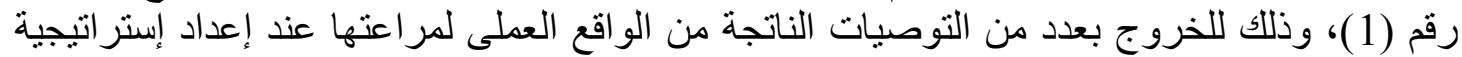
بناء القدر ات، منها:

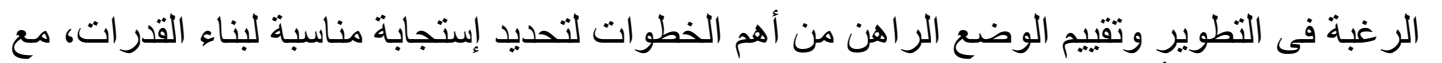

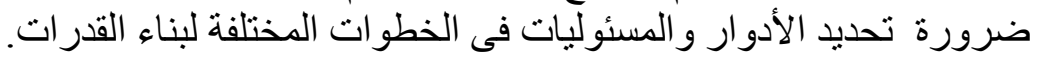

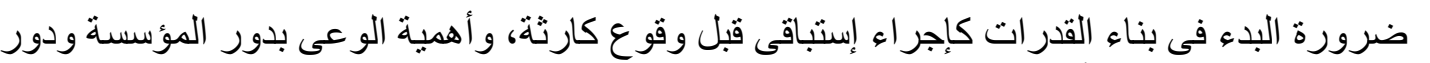
بناء القدر ات فى تفعيل أدوار المؤسسات الحيوية.

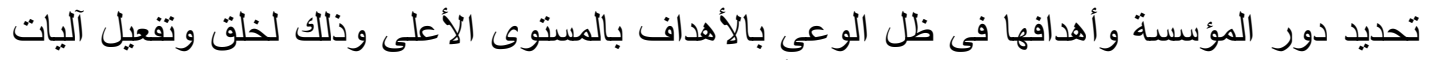

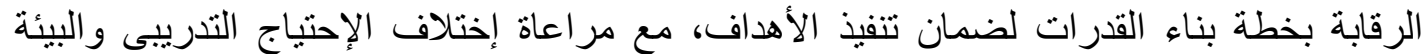
المحلية عند تصميم البر امج التدريبية، ومحاولة الإستعانة بمدربين محليين لخلق قاعدة خبر اءعاء المحليين وضمان إستدامة الانتطة لأطول فترة.

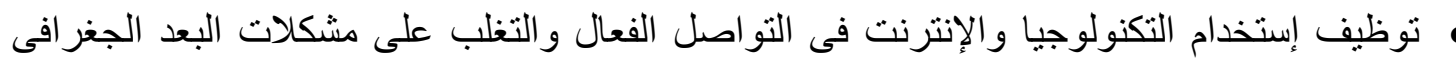
و الإستفادة من تبادل الخبرات ينعكس سريعا على عمليات التطور و التتمية.

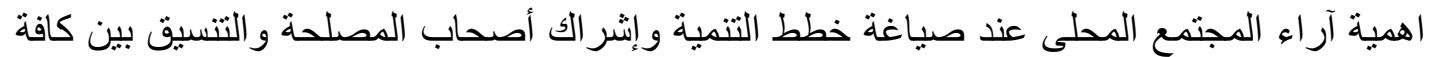
الأطر اف المعنية للتأكد من عدم التداخل، والإستفادة من تعدد آليات جمع البيانات وأهمية التغذية لتهنة الر اجعة في إعداد مخططات التنمية. • من أهم التحديات التى تواجه بناء القدرات تأثثير البيئة التشريعية وكذلك دورات العمل وفاعلية المؤسسة فى اداء دور ها. 


\section{جدول رقم (1) حالات تطبيقية لعملية بناء وتنمية القدرات1}

\begin{tabular}{|c|c|c|c|c|c|}
\hline أوجه الإستفادة & & الاجراءات & & ) & D) \\
\hline 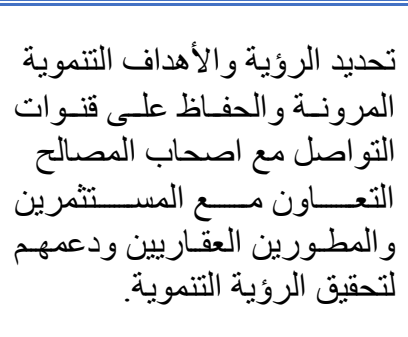 & & 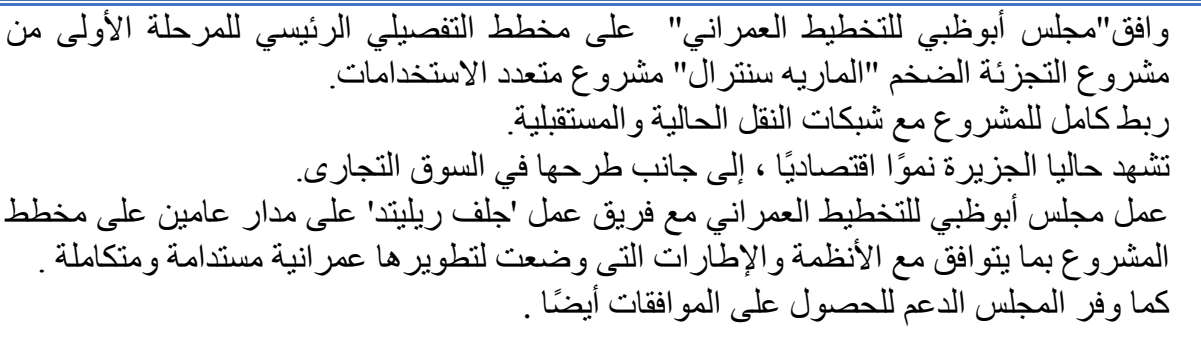 & 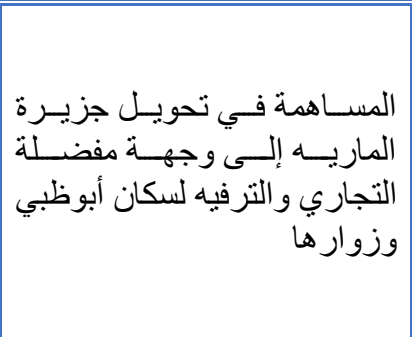 & 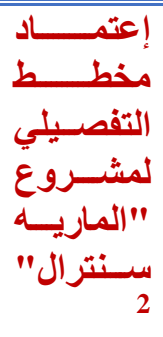 & $\frac{5}{5}$ \\
\hline 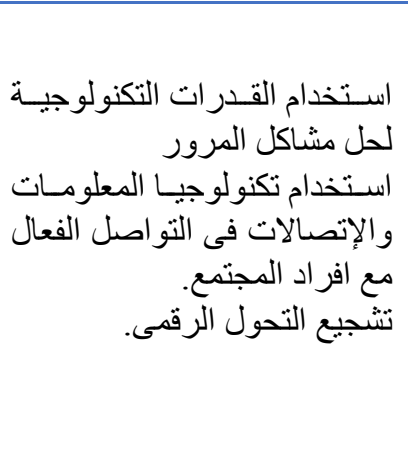 & $\bullet$ & 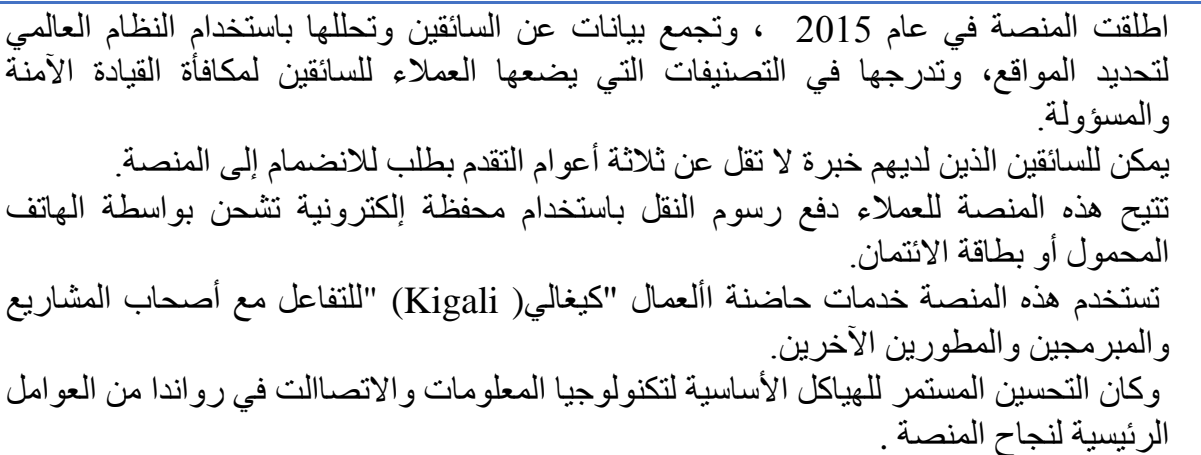 & 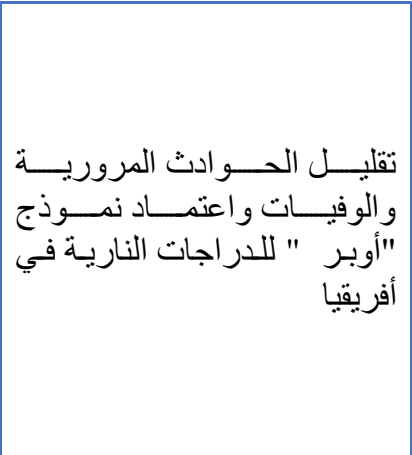 & الآمندة اجة & \\
\hline أهيات آلياتة جمع البيانات. & & 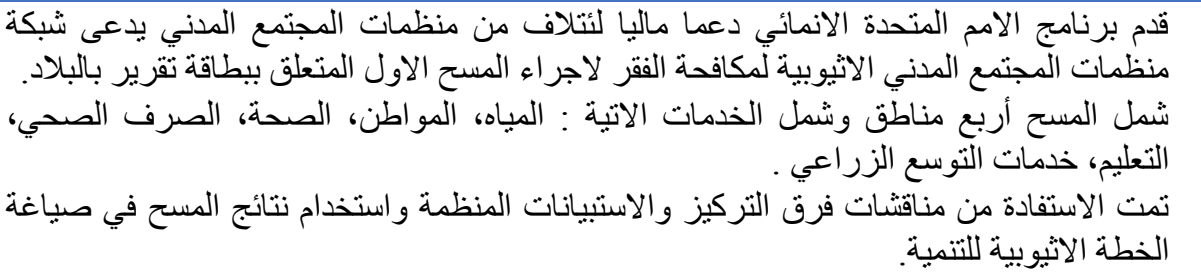 & 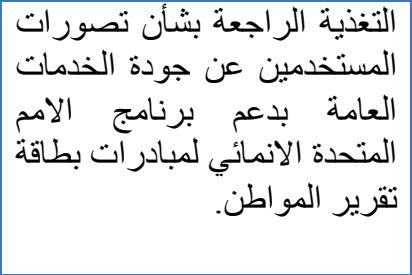 & 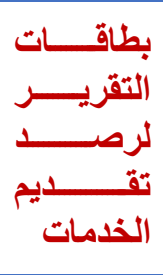 & E \\
\hline
\end{tabular}

\section{${ }^{2}$ https://www.facebook.com/399653700076341/posts/1277242065650829/}

https://www.arab-api.org/images/training/programs/1/2016/359_P16020-2.pdf تجميع الباحث عن arab-horizon-2030-innovation-perspectives-sdgs-arab-region-arabic.pdf $\quad 2019$ - الإبتكار و النكنولوجيا من أجل التنمية المستدامة آفاق واعدة في المنطقة العربية لعام 2030- الأمم الدنحدة 


\begin{tabular}{|c|c|c|c|c|}
\hline أوجه الإستفادة & الاجراعات & القضية & ال ال & البلد \\
\hline 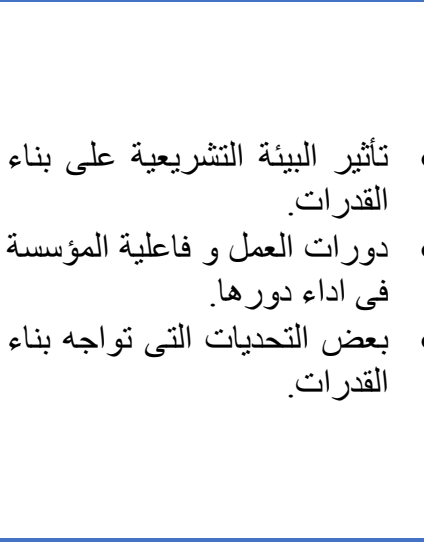 & 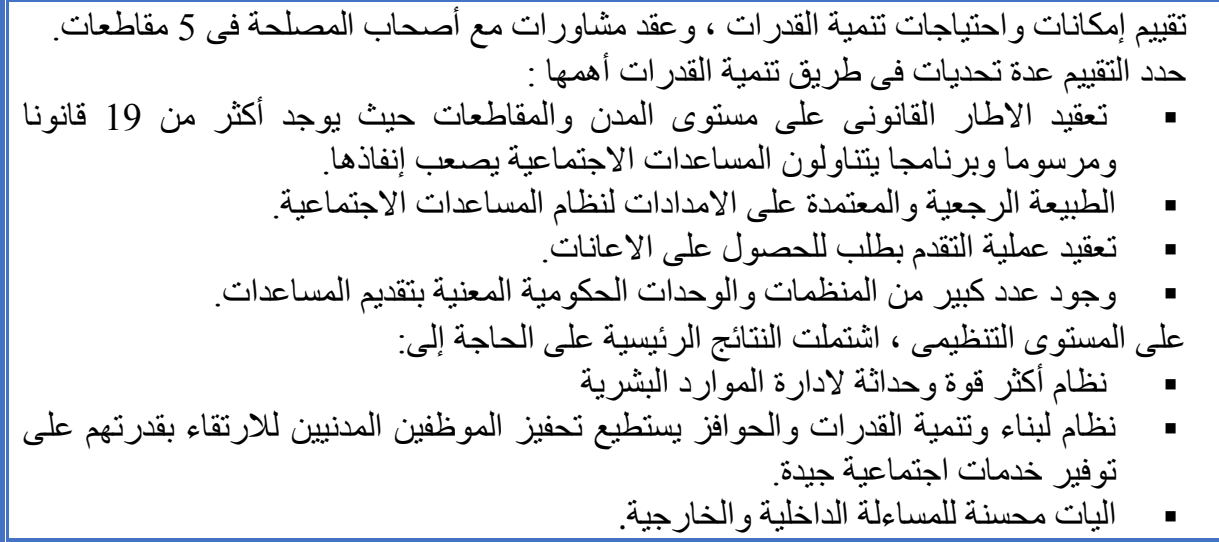 & 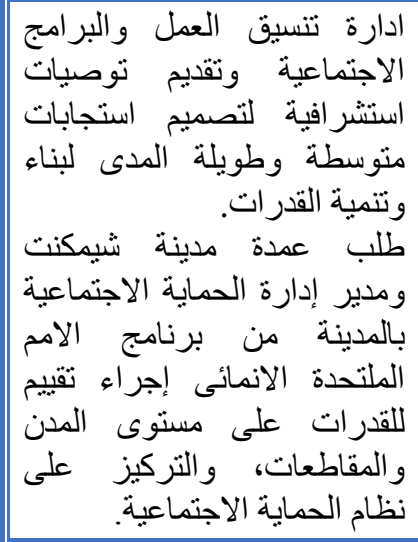 & 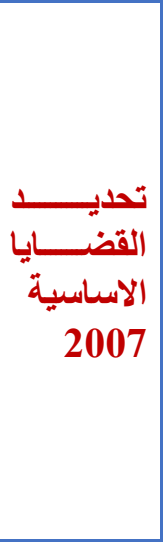 & $\frac{C \dot{C}}{\frac{C}{E^{*}}}$ \\
\hline 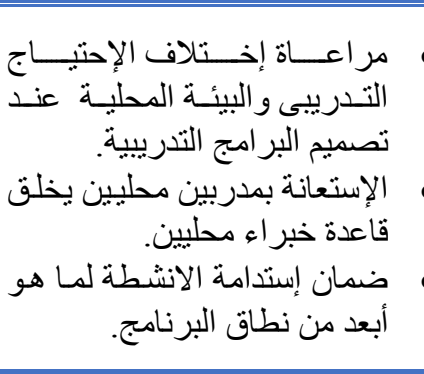 & 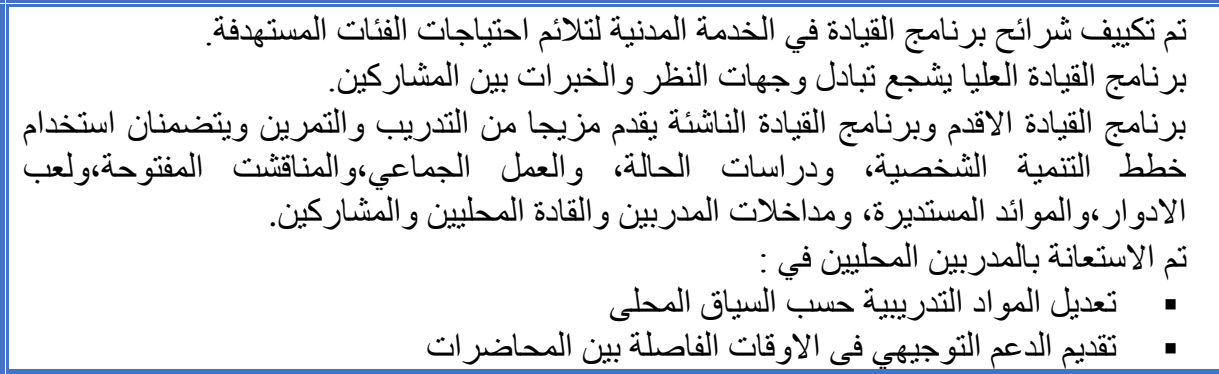 & 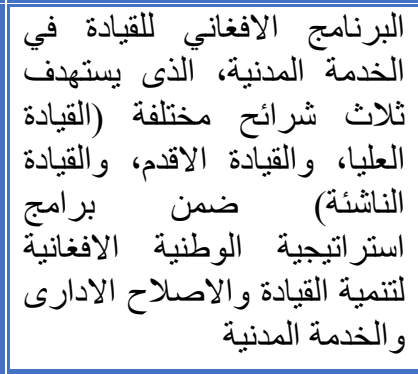 & 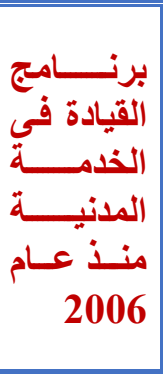 & \\
\hline 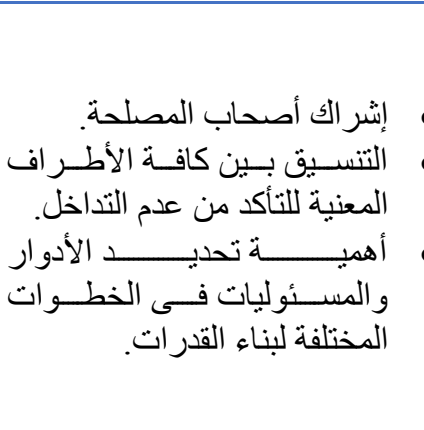 & 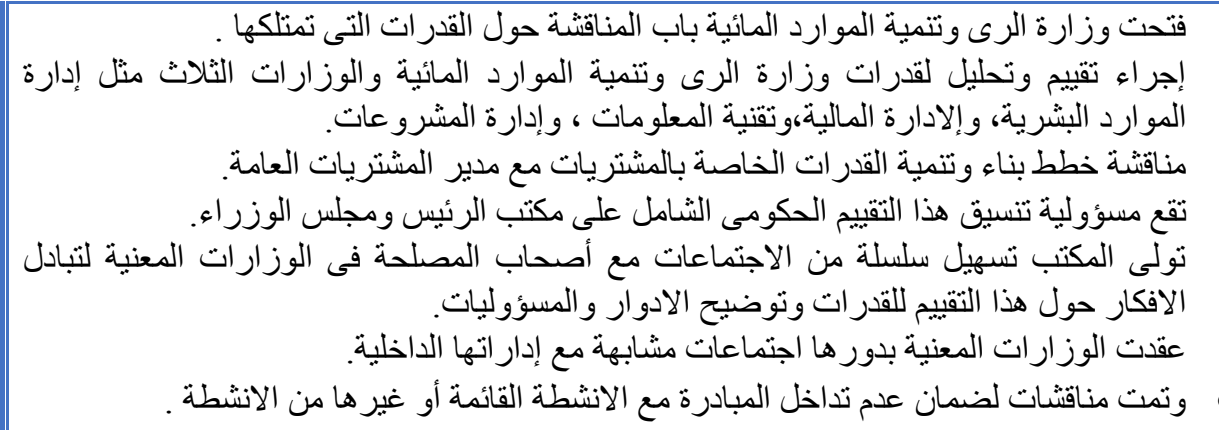 & 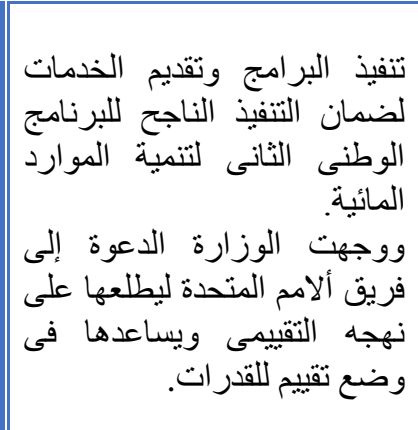 & 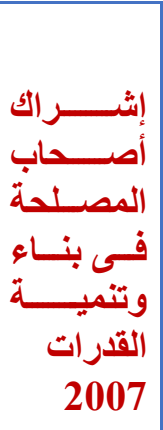 & G \\
\hline
\end{tabular}




\section{3- روية التطوير المؤسسى والتحول الرقمى لإدارات التخطيط العمرانى بالمحافظات}

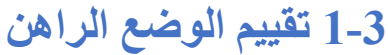

وتم ذلك من خلال تقييم الإطار المؤسسى والتنظيمى لعمل الإدارة وتقييم الكو ادر البشرية بالإدارة وتقييم

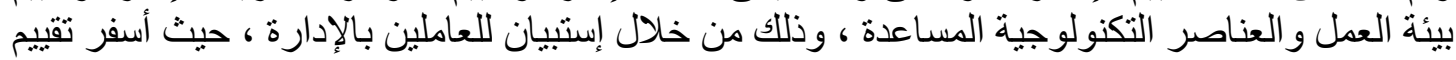

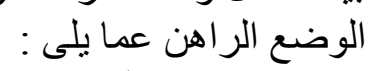

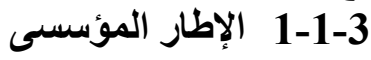

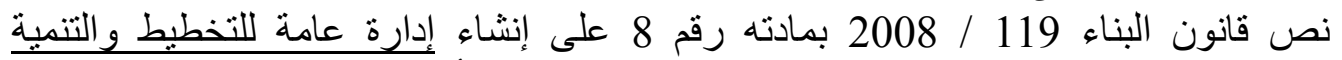

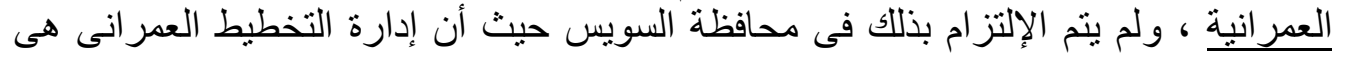

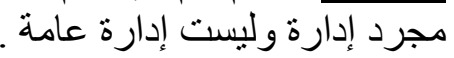

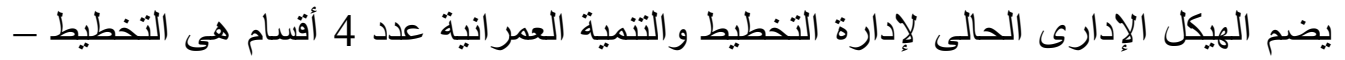

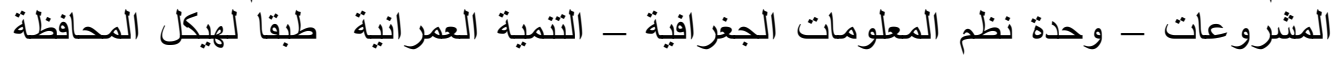

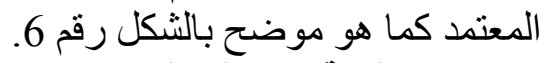
شكل رقم (6) الهيكل الإدارى لإدارة التخطيط والتنمية العمرانية بالسويس

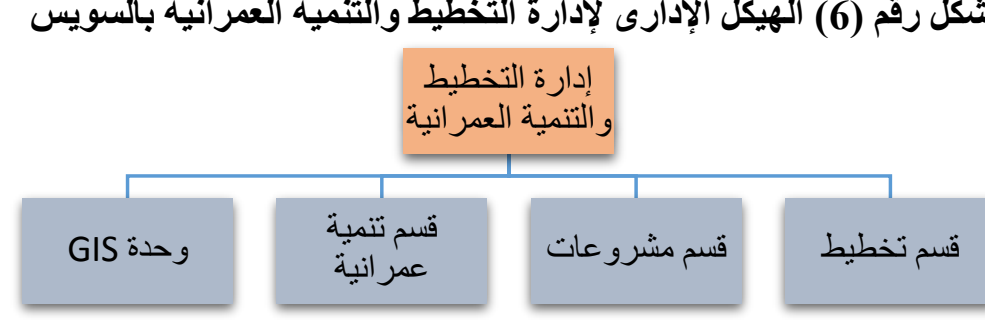

المصدر : الهيكل التنظيمى لديو ان عام محافظة السويس - إدارة الموارد البشرية بالديوان العام

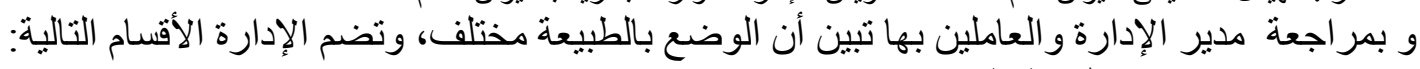
1-

2- - قسم البحوث (قديم و غير مدرج بالهيكل المعتمد)

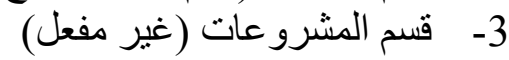

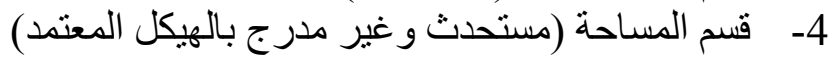

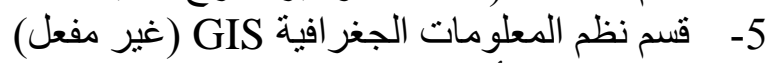

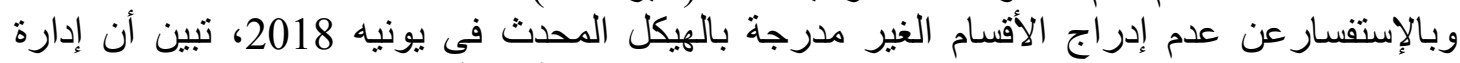

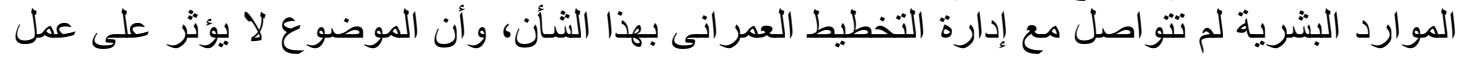

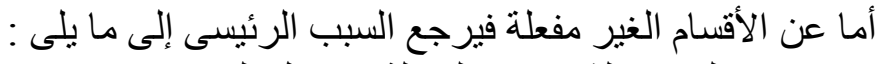

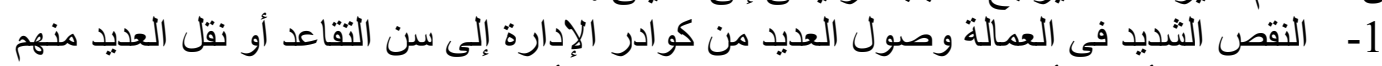

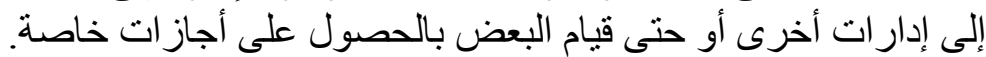

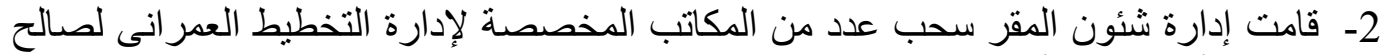

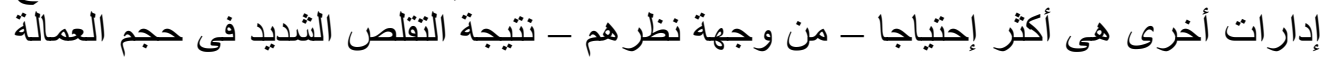

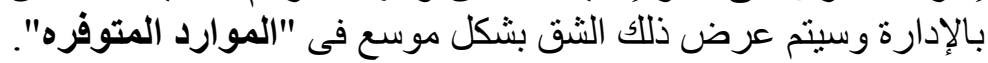

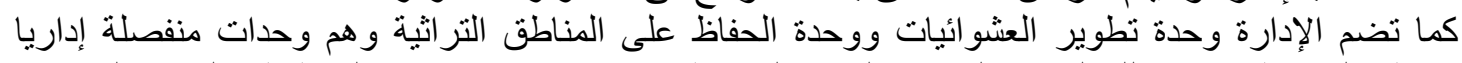
بمعظم المحافظات ، وذللك لنقص الكوات التحر الفنية بالمحافظة ، وقيام كوادر إدارة التخطيط و التنمية العمرانية

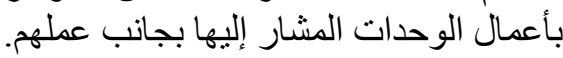
2-1-3 الكوادر الفنية الكيان

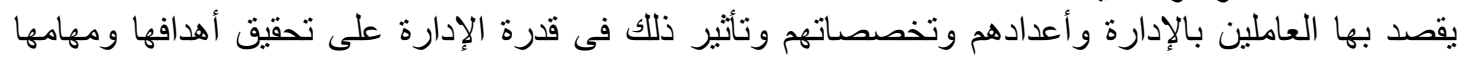

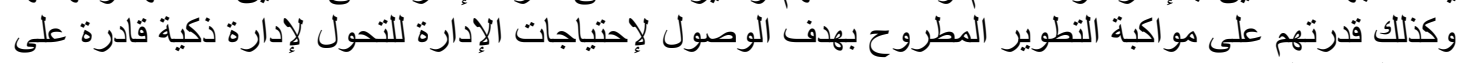
دعم التنمية العمر انية.

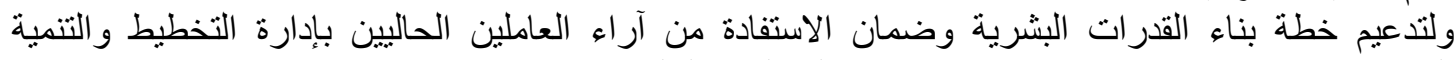

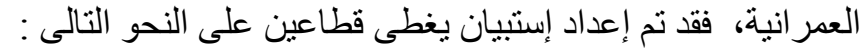

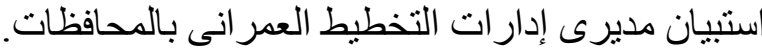
استبيان العاملين بإدارة التخطيط والتئية التخطية العمر انية بمحافظة السويس. 


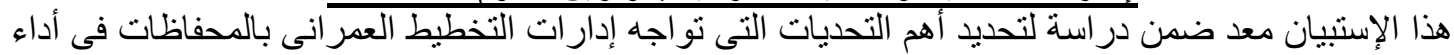

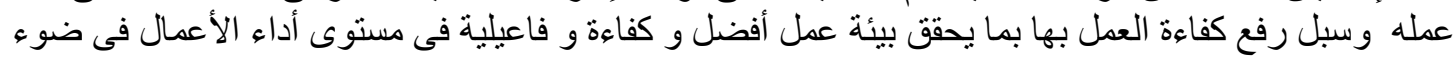

$$
\text { تاريخ الإستبيان : / / | ( } 2021
$$$$
\text { توجه الدولة نحو التحول الرقمى. }
$$

مدة شغل الوظيفة :

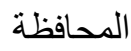

У

1. هل إدارة التخطيط و التنمية العمر انية بمحافظتلك إدارة عامة ؟ نعم 2.

3. كم عدد المدن القائمة التى تم إعتماد مخططات تفصيلية لها ؟

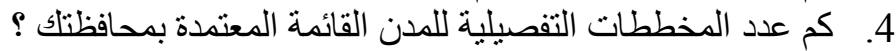

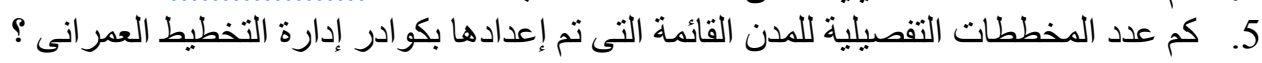

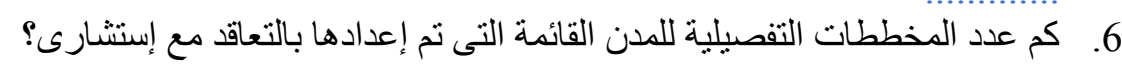

7. ما هى المعوقات التى واجهة إدارة التخطيط العمر انى فى إعداد و إعتماد المخططات التفصيلية للمدن

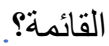

$\gamma$

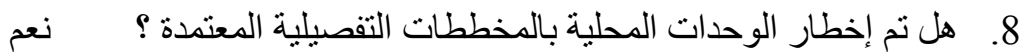

9. ما هى اليات إدارة التخطيط العمر انى لمتابعة تنفيذ والإلتز ام بالمخططات التفصيلية للمدن القائمة؛

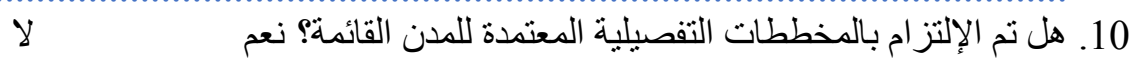

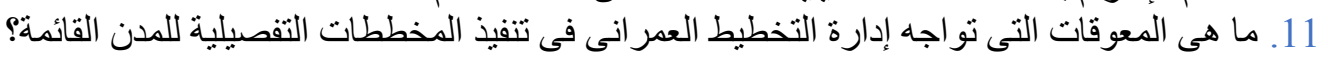

$$
\begin{aligned}
& \text { 12. كم عدد العمالة من المهندسين بإدارة التخطيط و التنمية العمر انية فى تخصص (تخطيط عمر انى - عماره } \\
& \text { - مدنى) ؟ }
\end{aligned}
$$

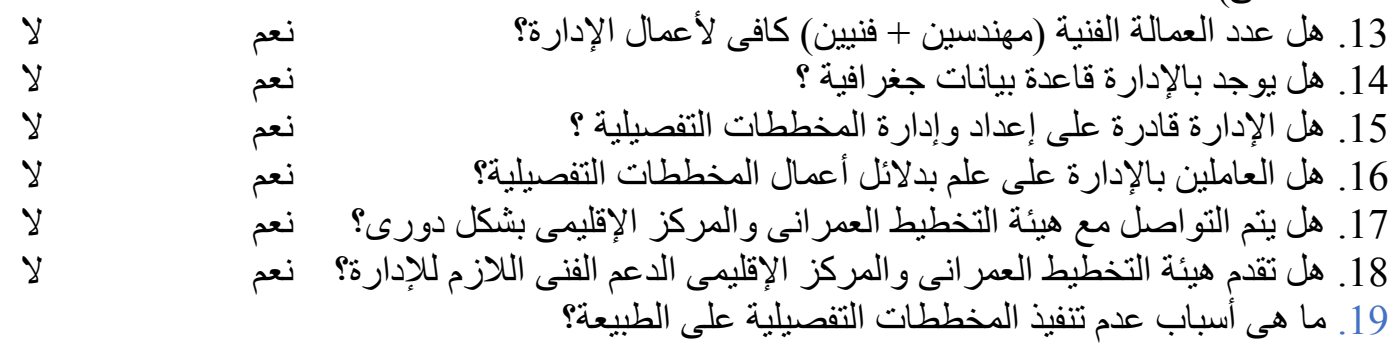

20. ما هى المتطلبات لتمكين إدارة التخطيطو التتمية العمر انية من إعداد و إدارة المخططات التفصيلية للمدن 
أولاً: تحليل نتائج استبيان العاملين بإدارات التخطيط العمر انى بالمحافظات

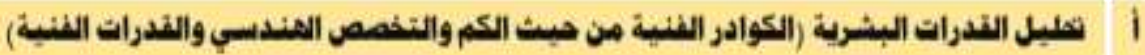
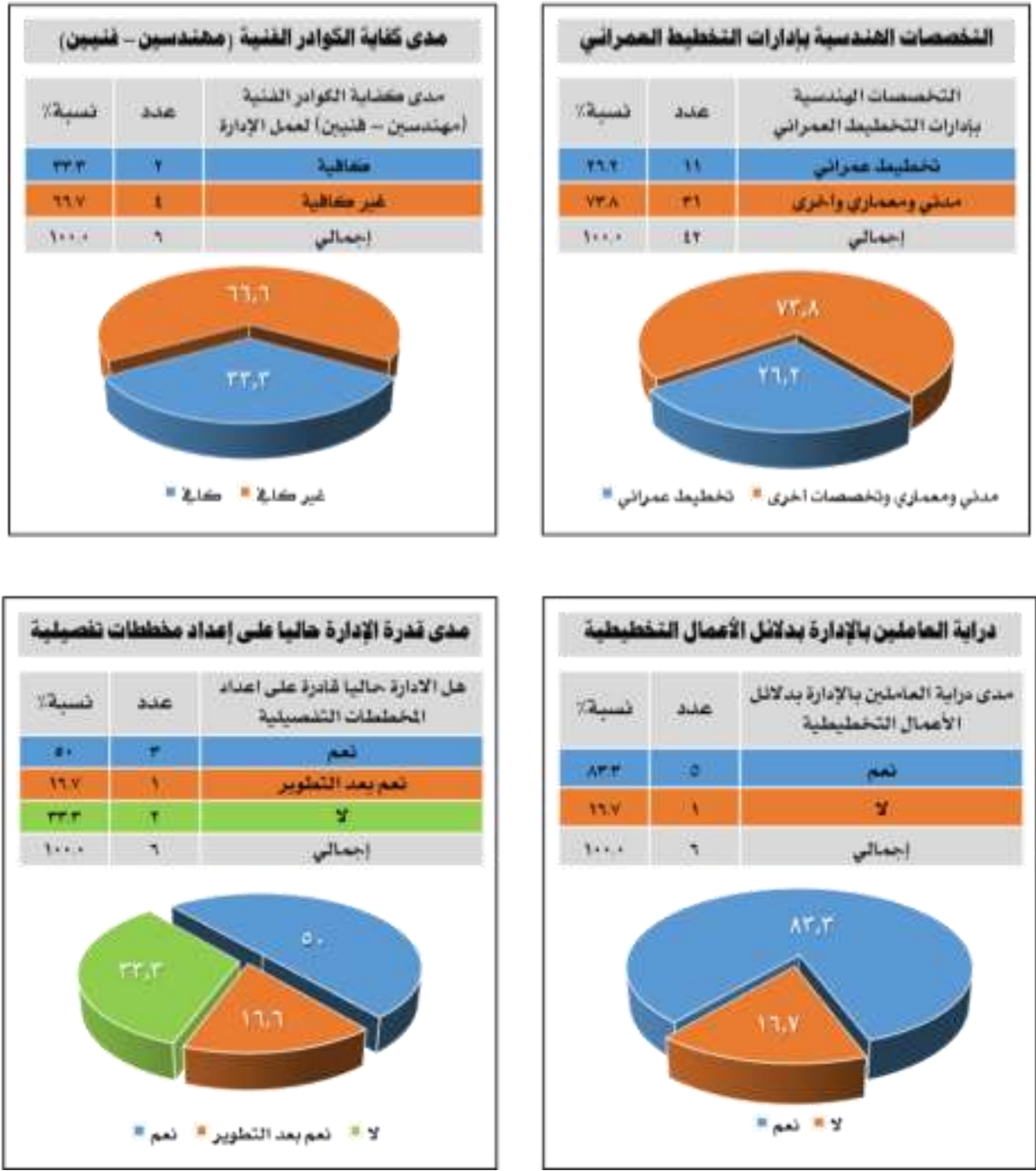

قدرات الإدارات (تواعد الببيانات -أعداد المخطاتات التفصيلية - التواصل مه الجمات المركرية)
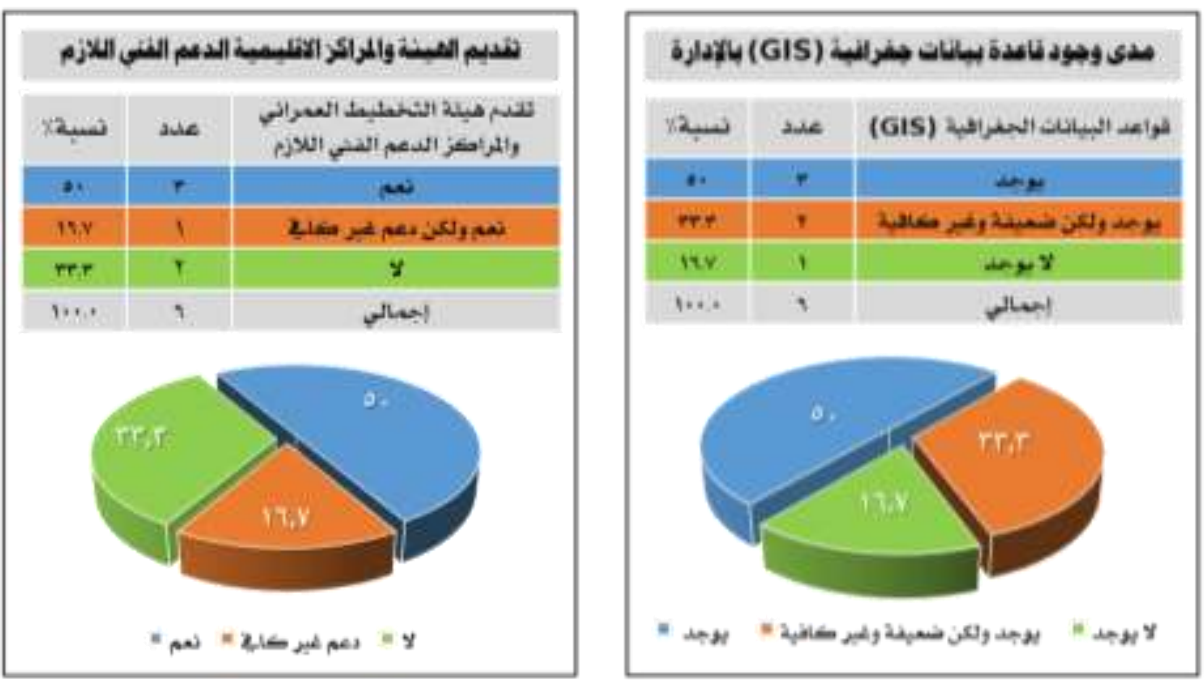


\section{إستبيان}

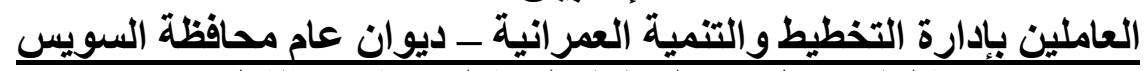

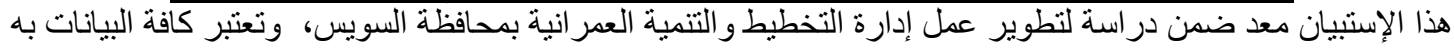

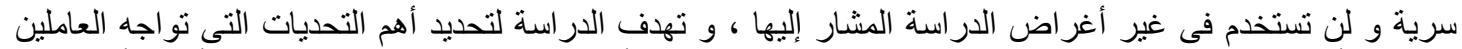

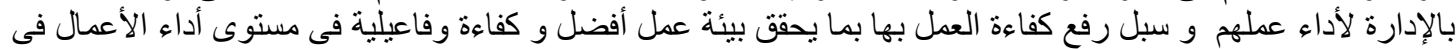

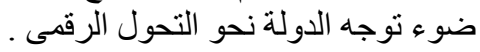

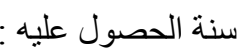
الاسم : مدة شغل الوظيفة :. المؤهل : الاسئ :

• ما هى طبيعة عمل إدارة التخطيط العمر انى (من وجهة نظرك) ؟

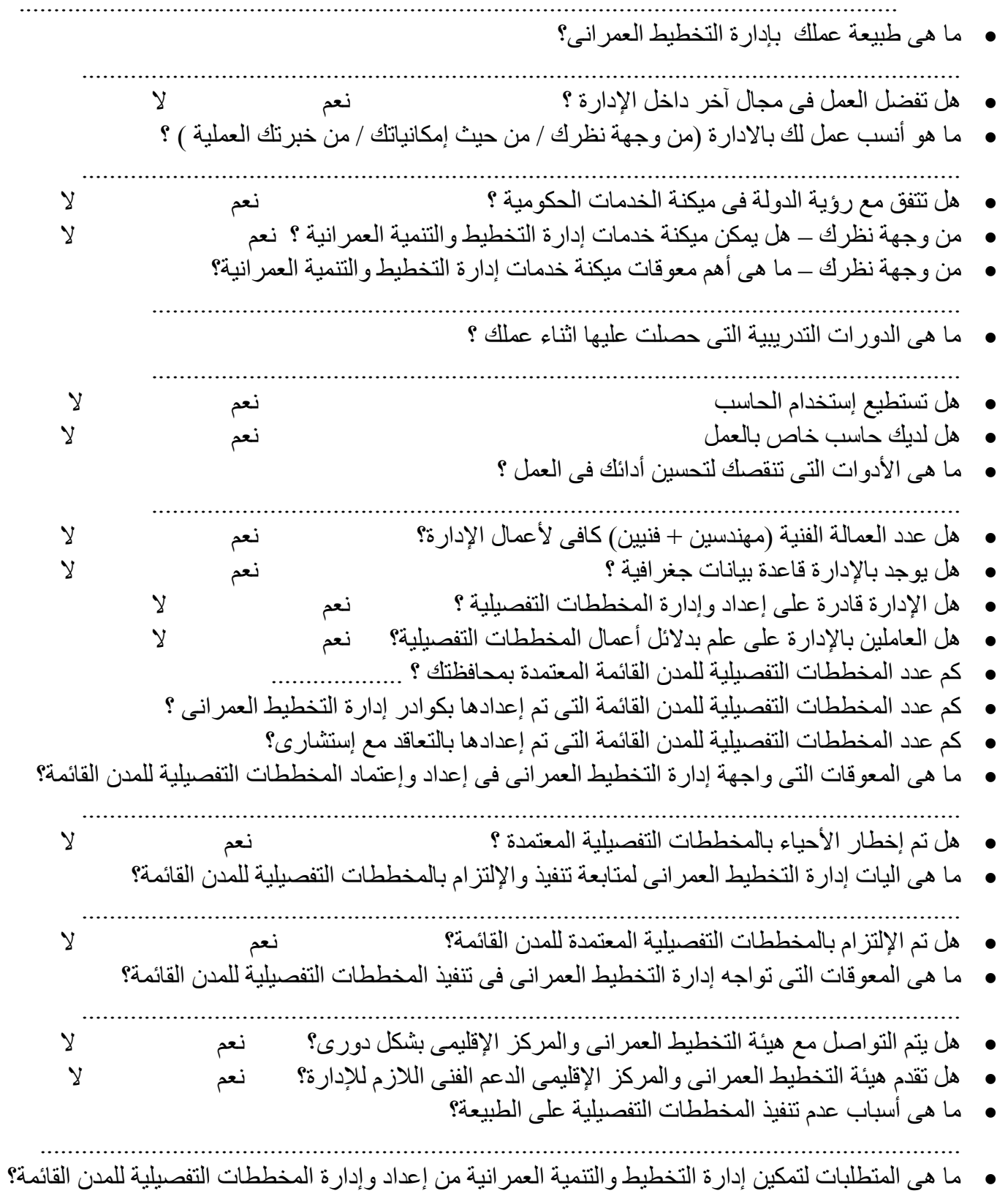


ثانيا: تحليل نتائج استبيان العاملين بإدارة التخطيط العمرانى بالسويس
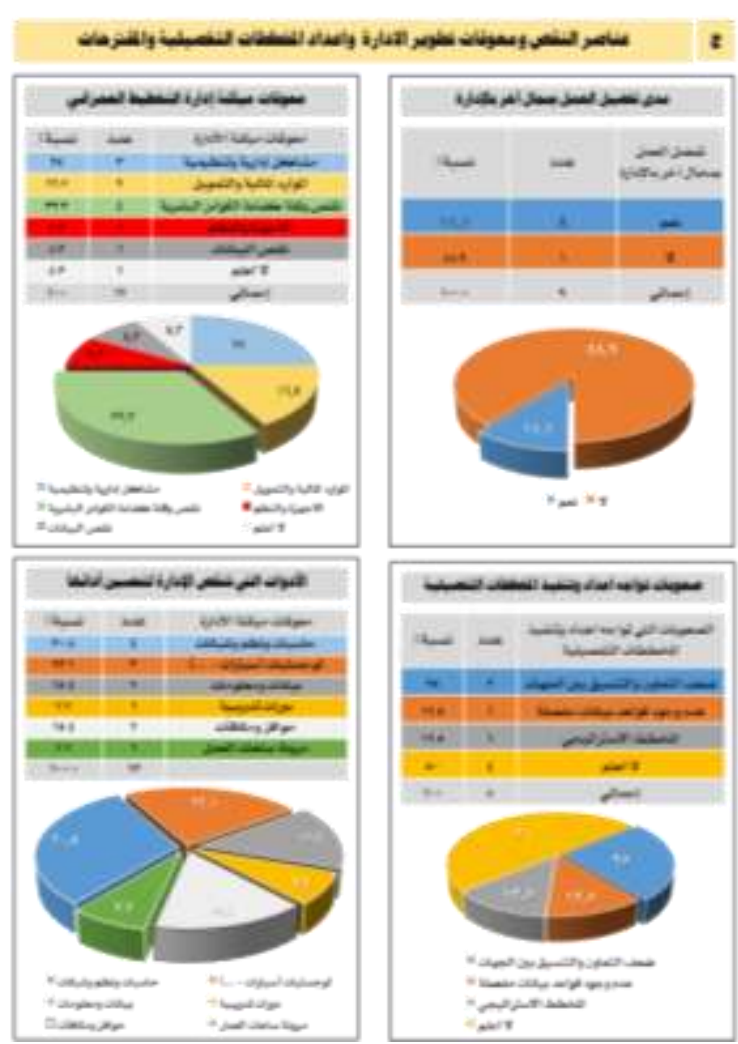
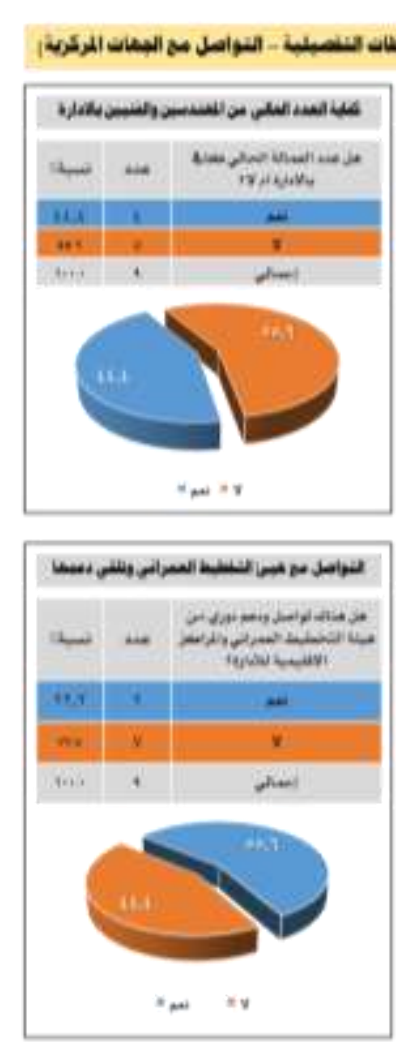
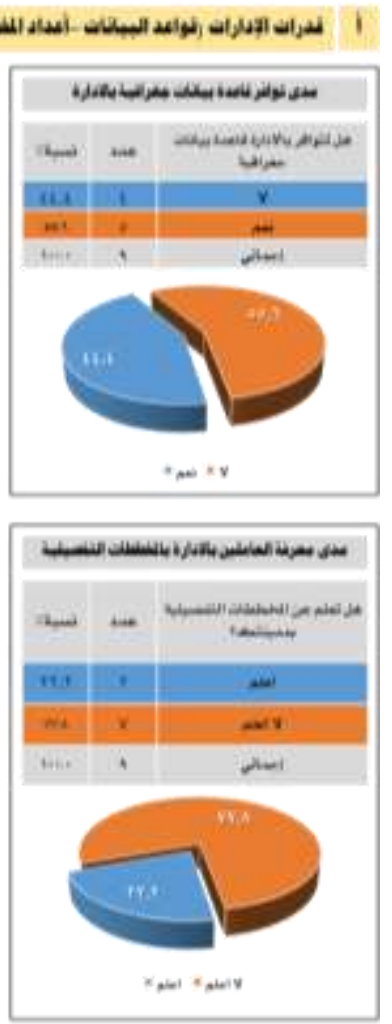
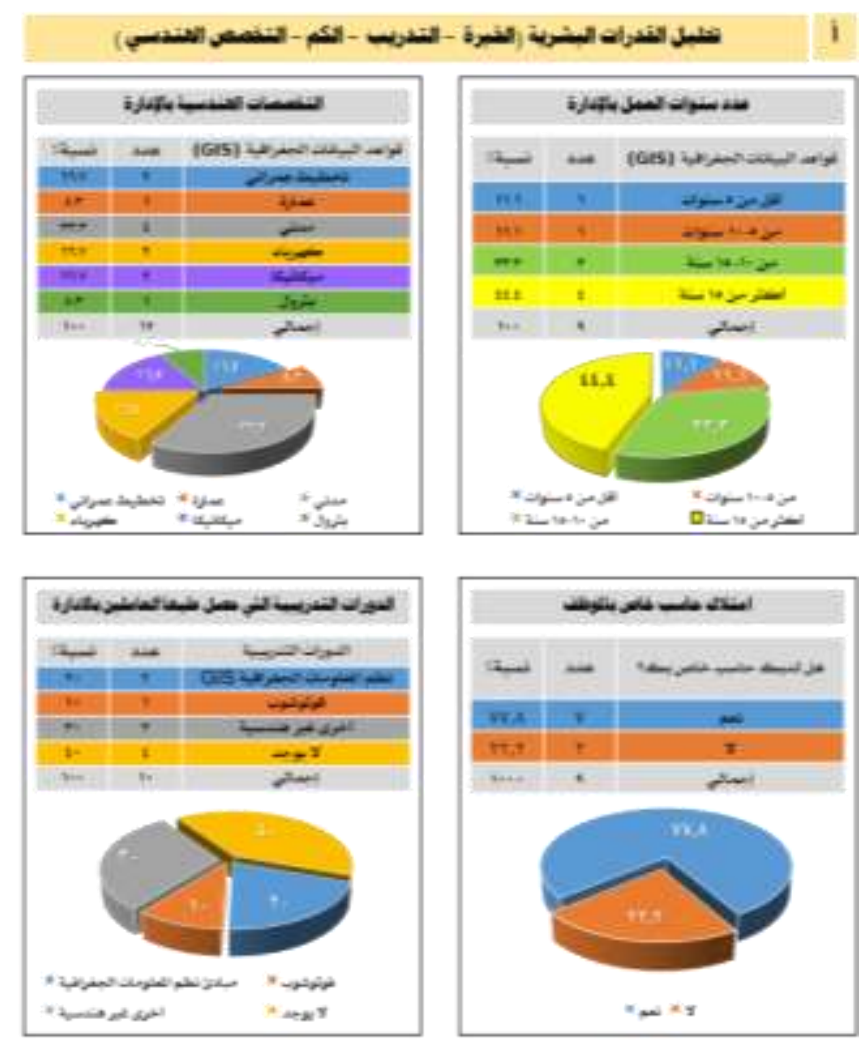


\section{وفيما يلى نتناول تحليل نتائج الاستبيان:}

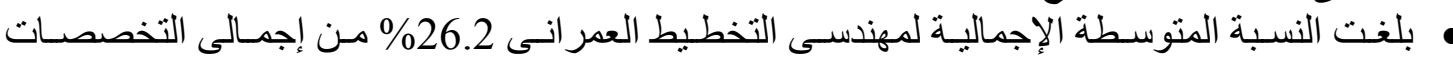
الهندسية بإدارات التخطيط العمر انى على مستوى المحافظات التى شملتها العينة مقابل

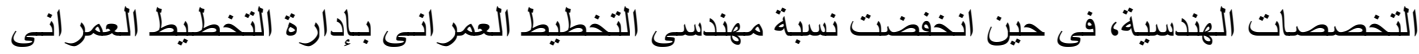

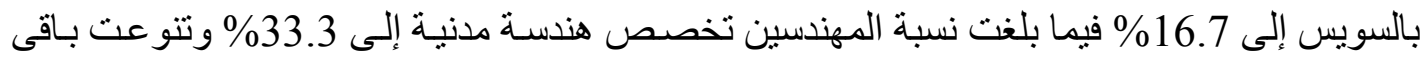

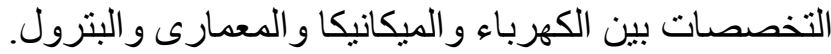

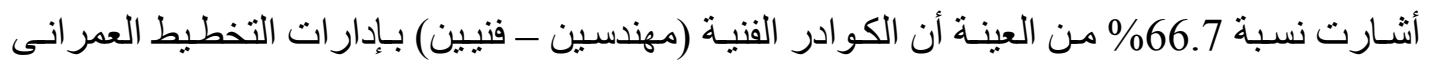

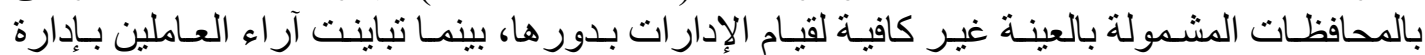

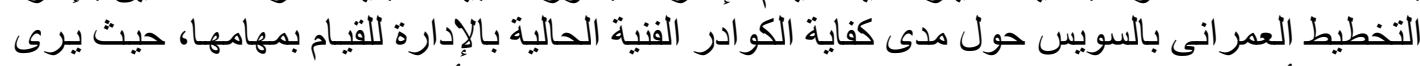

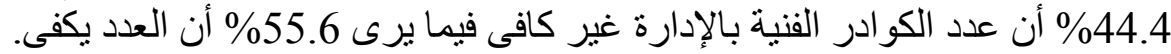

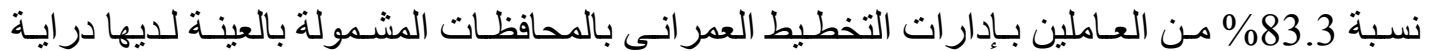

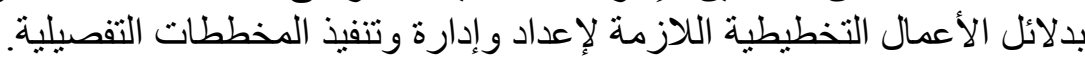

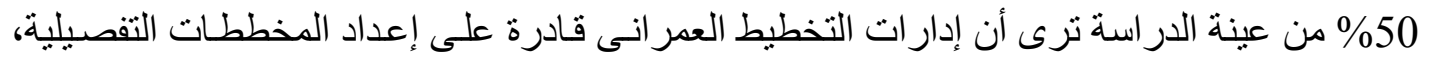

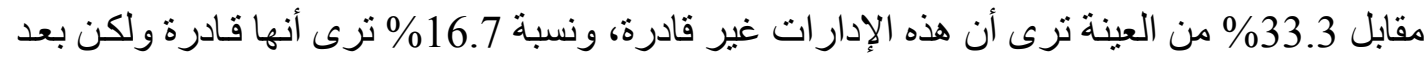
التطوير.

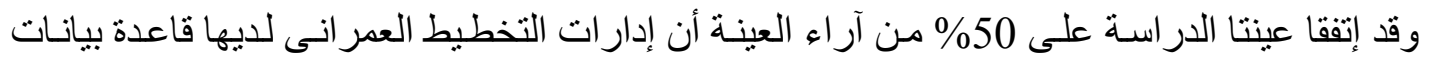

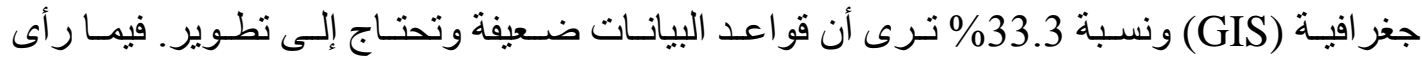

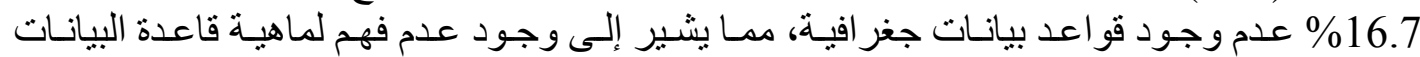

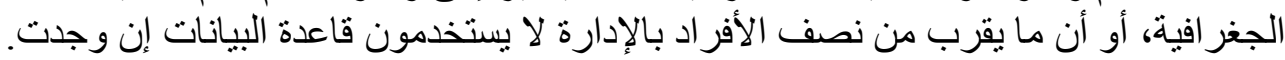

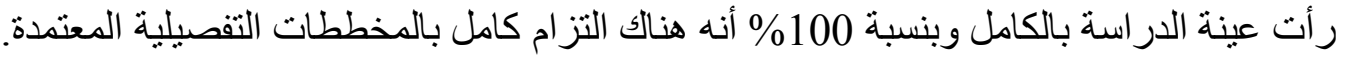

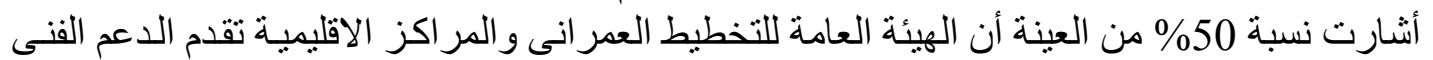

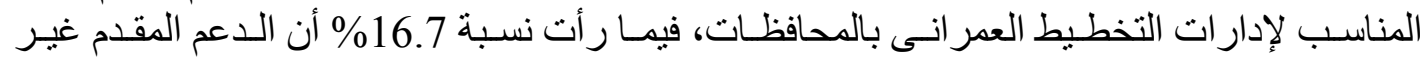

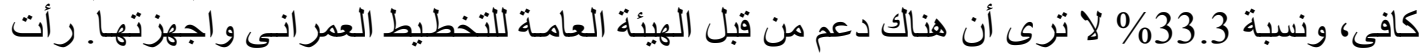

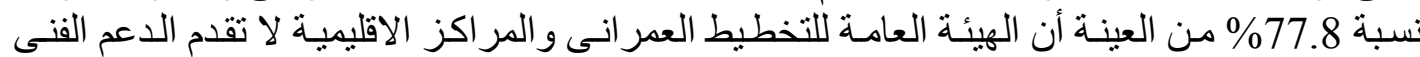

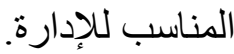

\section{وفيما يخص استبيان العاملين بإدارة التخطيطو التنمية العمرانية بمحافظة السويس:}

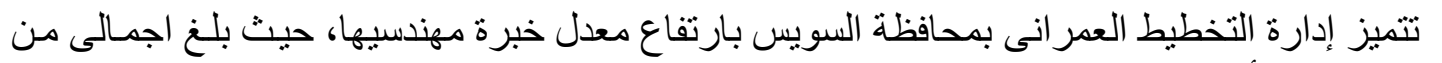
لديهم خبرة أكثر من 10 سنوات نسبة 77.7 \%

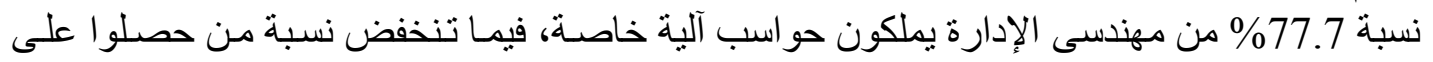

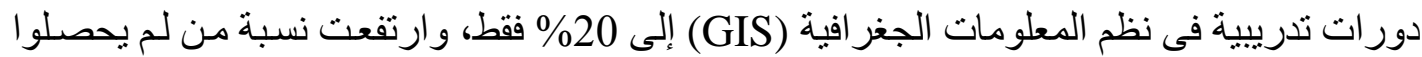

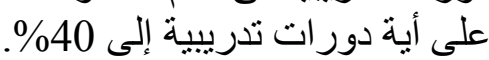
ن نسبة 77.7\% لديهم معلومات مفصلة عن المخططات التفصيلية بمدينة السويس. نسبة 88.9\% مـن العينـة يرون أن المهام التى يقومـون بهـا حاليـا داخل الإدارة مناسبة و لا يفضـلون تغيير هذه المهام. أسباب عدم تنفيذ المخططات التفصيلية على الطبيعة:-

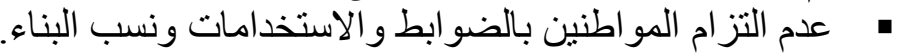
- ضعف الأجهزة القائمة على التخطيط ومركزية عملية التخطيط. • ضعف البنية التحتية و التكنولوجية والأجهزة الميدانية و النظم التطبيقات الجغر الفية النية. عدم مطابقة المخطط لما هو بالطبيعة خاصة بمناطق الامتداد لعدم در اسة الملكيات. عدم دقة المخططات التفصيلية. عدم وضوح حدود الملكيات. ضعف التعاون و التنسيق بين الجهات. عدم وجود قوا اعد بيانات مفصلة. صعوبات تتعلق بالمخطط الاستر اتيجى. 
هتطلبات تمكين إدارة التخطيط العمرانى لإعداد المخططات التفصيلية للمدن:

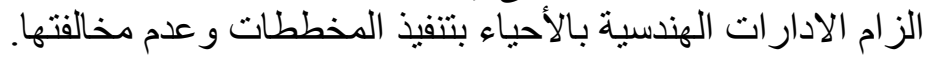

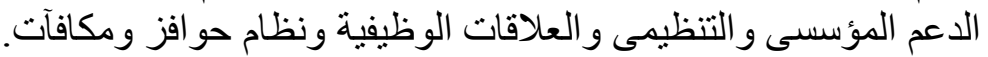

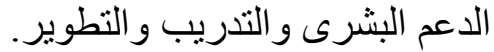
الدعم التكنولوجى و المعلوماتى وقو اعد البيانات.

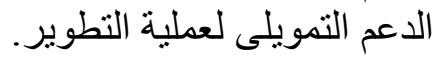
توفير و إعداد خر ائط اساس متكاملة خر ائط لنشبكات المر افق طبقا للطبيعة.

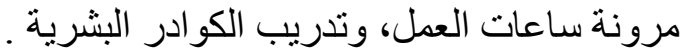

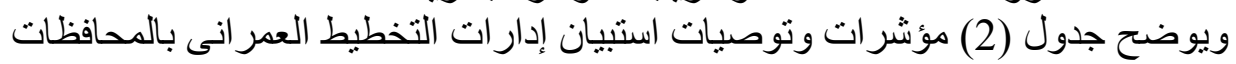

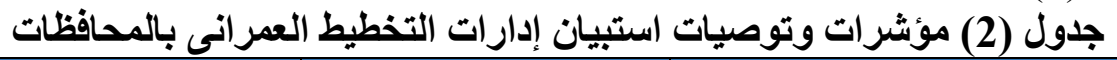

\begin{tabular}{|c|c|c|c|}
\hline الثتوصية & المؤشر & تتية عينة الاستبيان & P \\
\hline 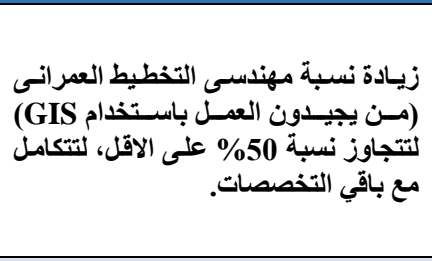 & 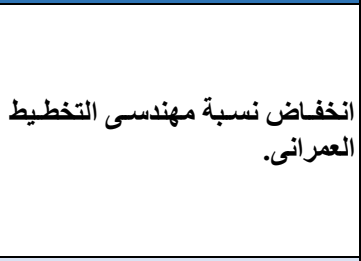 & 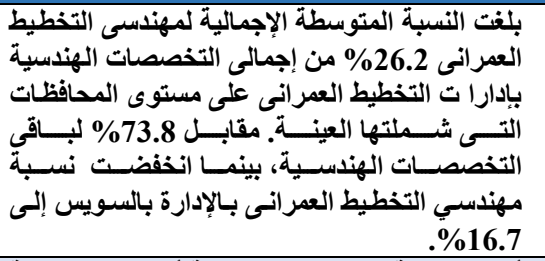 & 1 \\
\hline 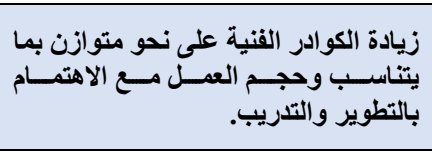 & 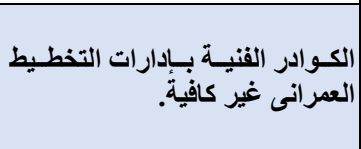 & 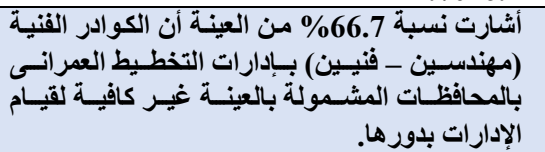 & 2 \\
\hline 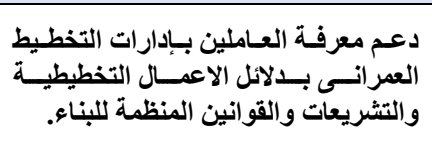 & 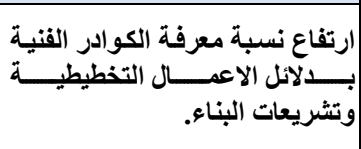 & 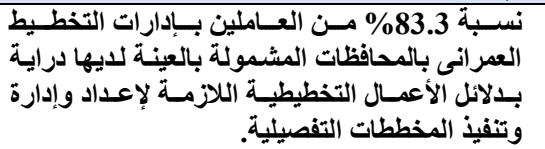 & 3 \\
\hline 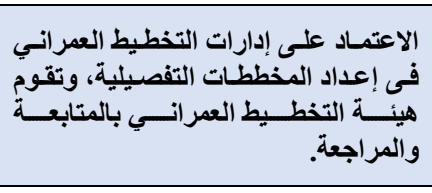 & 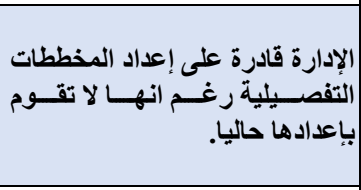 & 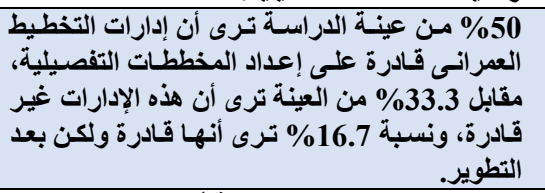 & 4 \\
\hline 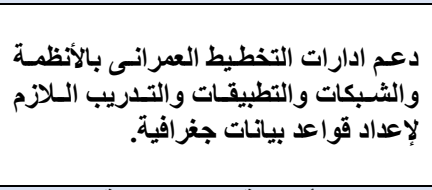 & 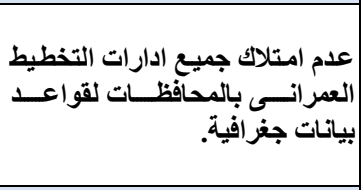 & 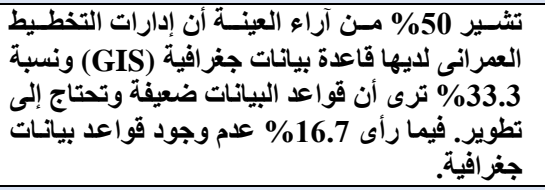 & 5 \\
\hline 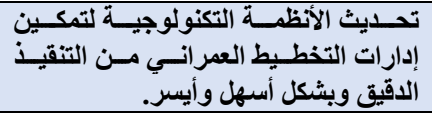 & عند التنفيذ. & 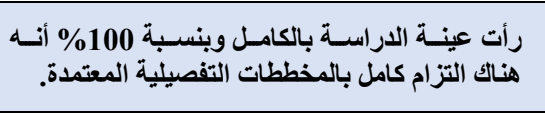 & 6 \\
\hline 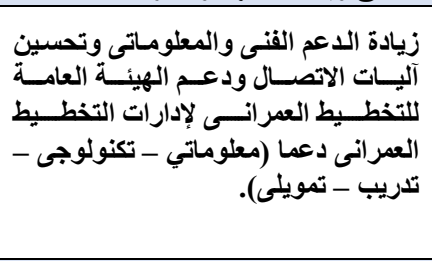 & 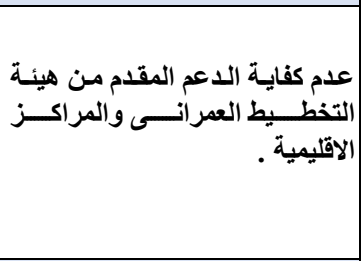 & 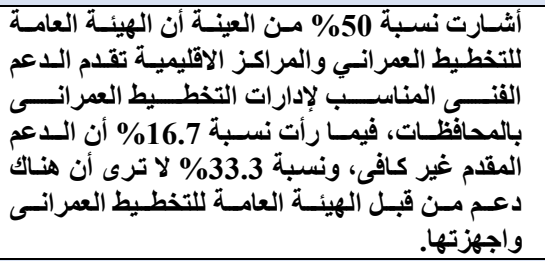 & 7 \\
\hline 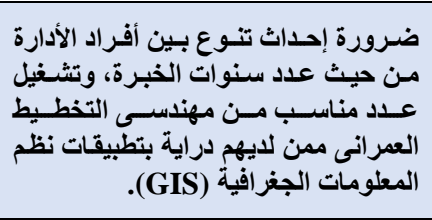 & 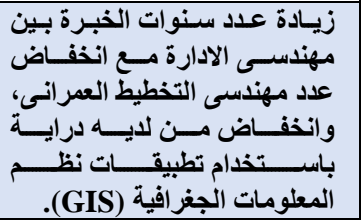 & 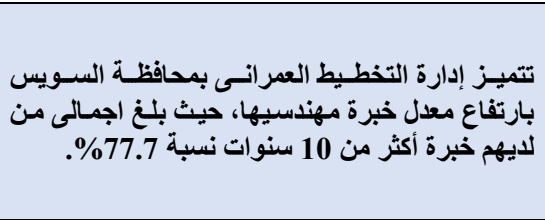 & 8 \\
\hline 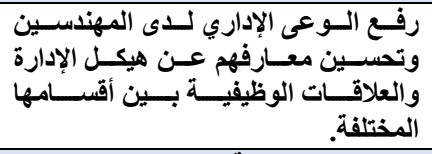 & 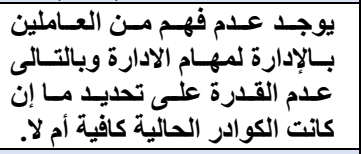 & 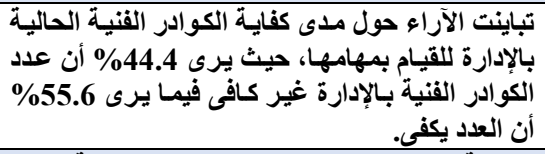 & 9 \\
\hline يخص المخططات التفصيلية. ولتوري بكل مـا & المغططات التفصيلية جيدة. الإدةرة عـن & 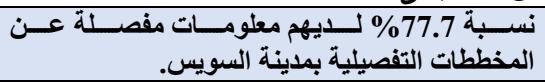 & 10 \\
\hline 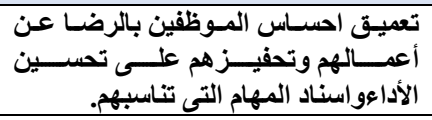 & عن الرضام العام من العاملين بـالادارة & 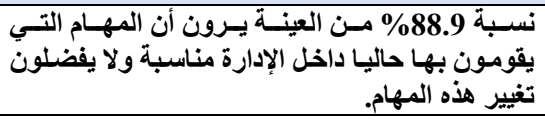 & 11 \\
\hline
\end{tabular}




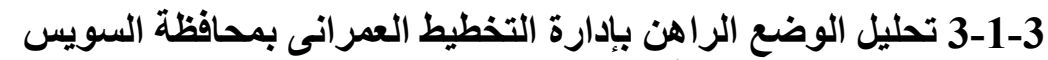

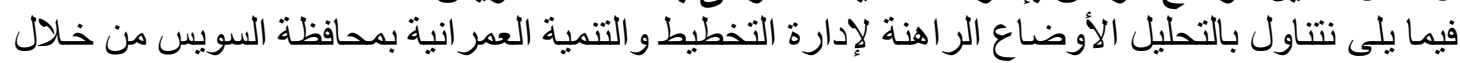

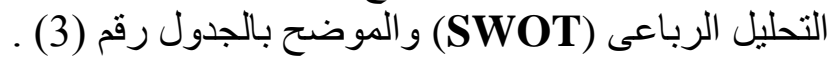
جدول رقم (3) التحليل الرباعى للوضع الراهن بإدارة التخطيط العمرانى بالسويس WEAKNESS 1 1. العجز الثديد فى العمالة الفنية وهروب الكفاءات. 2. عدم وجود قو اعد بيانات.

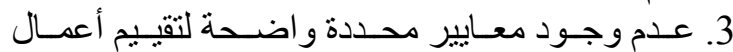

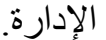

4. غياب الرؤية و عدم وضوح مهام الأدام الإدارة للعاملين بها. 5. ضعف كفاءة الإداريين بالإدارة وعارة

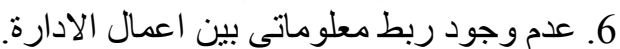
7. غياب الحافز و عدم وجود نظام للإثابة.

\section{THREATS}

1. ضعف البنية التكنولوجية بالمحافظة.

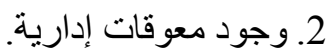

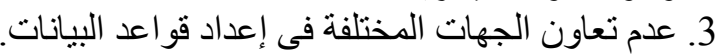
4. ضعف المخصصات المالية للمحافظات.

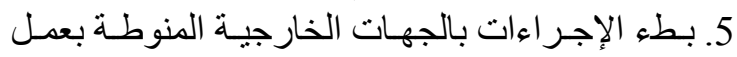
المشروع. 6. وقف التعينات بالقطاع الحكومى. 7. رفض تعديل الهيكل الادارى.

\section{STRENGHTHS}

1. وجود مخططات عمر انية (استر اتيجية - تفصيلية) وحيز عمر انى معنمدة.

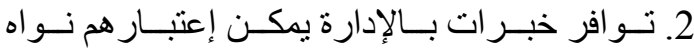
للتطوير.

3. تو افر عدد من أجهزة الكمبيوتر يمكن البدء بها. 4. التعامل بروح الفريق بين العاملين بالإدارة.

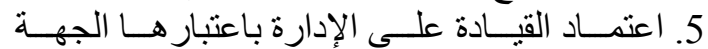
المندسية بالديوان.

\section{OPPORTUNITIES}

1. رؤية سياسية داعمة لإستخدام التكنولوجيا. 2. وجود قسم جغر افيا بكلية الآداب جامعة السويس. 3. 2. وجود المر اكز التكنولوجية.

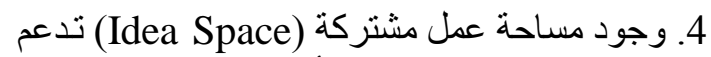

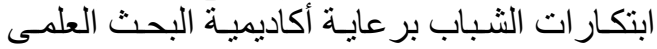
بالسويس. 5. ظهور العديد من مر اكز تدريب بالسويس تهنت بـ و التى لاقت اقبال شديد. 6. نشاط العديد من شركات القطاع الخـاص و المجتمع لإن

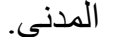

نتائج التحليل الرباعى لبيئتى العمل الداخلية والخارجية

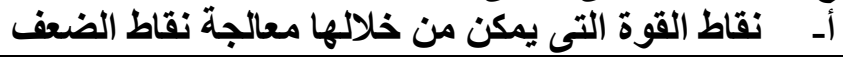

\begin{tabular}{|c|c|c|}
\hline كيفية معالجة نقاط القوة لنقاط الضعف & نقطة الضعف & نقطة القوة \\
\hline استخدام الأجهزة و الكو ادر المتاحة فى البدء فى بناء قو اعد البيانات. & 3 & 3 ، 2 \\
\hline تشجيع العاملين على تبادل الخبرات و التأكد من فههم الصحيح لرؤية الإدارة. & 5 & 4 \\
\hline
\end{tabular}
ب- نقاط القوة التى يمكن من خلالها تجنب التهايدات

\begin{tabular}{|c|c|c|}
\hline كيفية مو اجهة نقاط القوة للتهديدات & التهديدات & نقطة القوة \\
\hline وذلى الجهات خلال التنغلال علاقات المناونة القيادات فى استعجال نهو الإجراءات و الضغط & 5 ، 3 & 5 \\
\hline
\end{tabular}

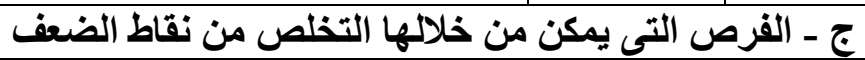

\begin{tabular}{|c|c|c|}
\hline كيفية معالجة نقاط القوة لنقاط الضعف & نقطة الضعف & فرصة \\
\hline وذلك بتطبيق نظم قياس معدلات الاداء ووضع منظومة لتقييم اداء العاملين. & 4 & 4 \\
\hline و مشاركة المؤسسات بتدريب العاملين الإداريين اوتوفير متطو عين لإرشاد الفنيين & 1، 6 & 8 \\
\hline
\end{tabular}

د ـ الفرص الممكن استغلالها للحد من التهايدات التهاتيات

\begin{tabular}{|c|c|c|}
\hline كيفية معالجة الفرص للتهديدات & التهايدات & 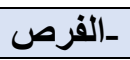 \\
\hline استغلال توجه الدولة نحو التحول الرقمى فى دعم البنية التكنولوجية. & 1 & 3 ، 1 \\
\hline استغلال الخريجين (فترة أداء الخذمة العامة) لسد العجز فى العمالة. & 6 & 2 \\
\hline من خلال اقناعهم بأهمية المشاركة فى دعم المشروع ماديا (تبر عات عينية / مادية). & 4 & 8 \\
\hline زيادة وعى المجتمع المدنى و استجابته للتغير ات المستهـفة نحو التحول لمدينة ذكية. & 7 & 7 ، 6، 5 \\
\hline
\end{tabular}


2-3 م خطة التطوير المقترحة بناءا على ماسبق تبين أهمية وضع خطة لتوحة لتطوير إدارةالتخطيط و التنمية العمر انية بالسويس لتحسين

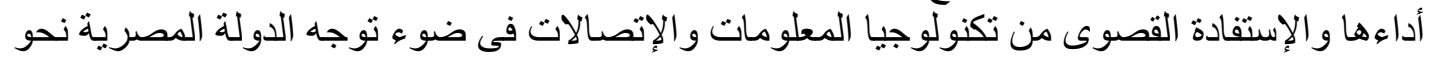

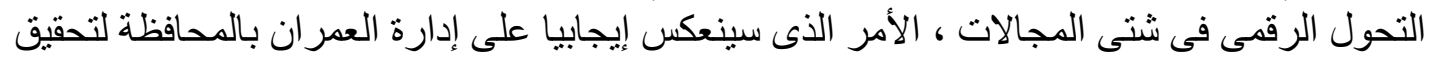
أهداف ومهام الإدارة. وقد تم صياغة خطة التطوير لتغطى الابعاد الأساسية لإحداث التطوير المرغوب ألتوب من البعد البشرى

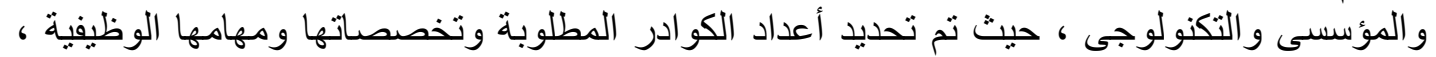

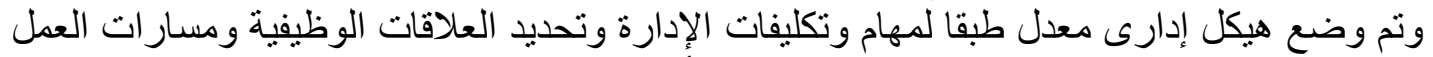

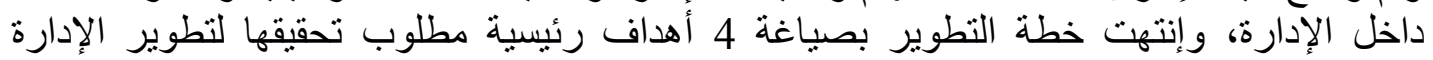
وتحقيق الإستفادة المتلى من التحول الرقمى التهى والخطوات التنفيذية لذلك من خلال مجموعة من الأنشطة

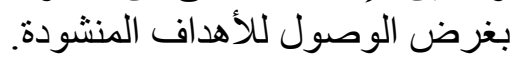
1-2-3 الكوادر البشرية تستهدف نطوير إدارة التخطيط والتنمية العمرانية، ويمكن التحدث عن التردية

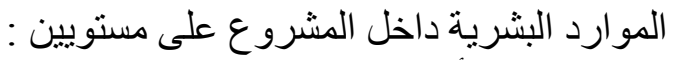

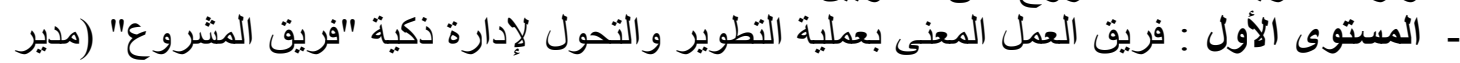

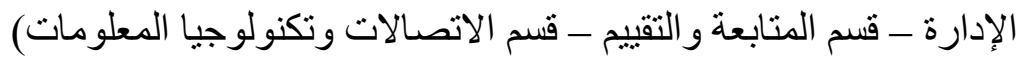
- المستوى الثانى : فريق عمل الإدارة المستهدف بعد الإند عملية التطوير (جميع اقسام الإدارة). شكل رقم (7) الهيكل الإدارى المقترح لإدارة للتنمية العمرانية

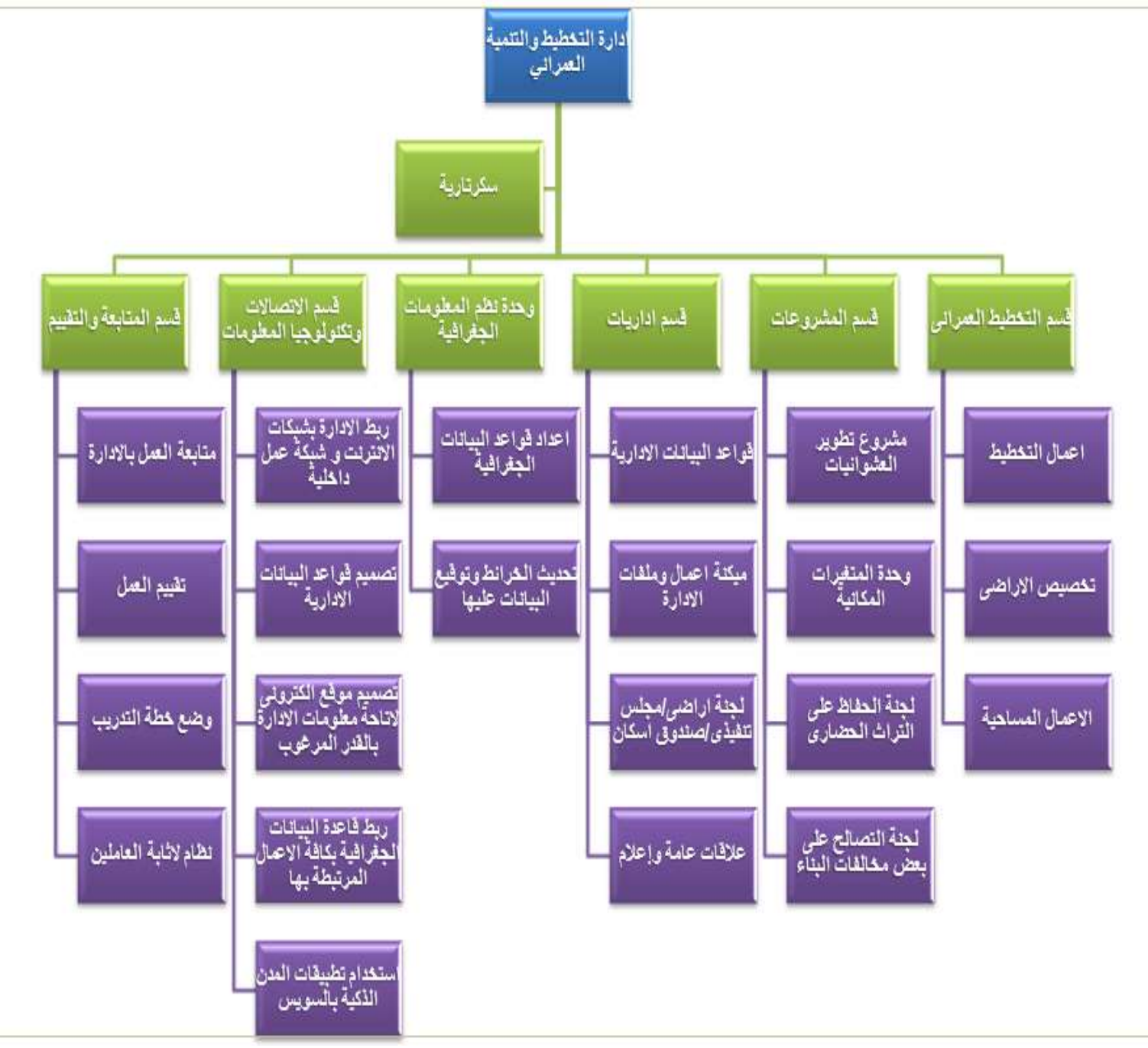


3-2-3 وصف للادوار و المسئوليات

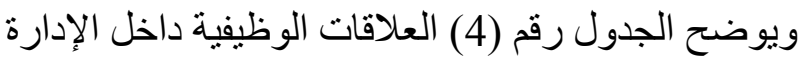
جدول رقم (4) العلاقات الوظيفية داخل الإدارة الإدة

\begin{tabular}{|c|c|c|}
\hline الادوار و المسئوليات & العدد & 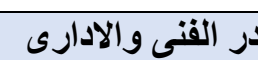 \\
\hline الاشر اف العام على الادارة ومتابعة الجودة والتطوير لاساليب و اليات العمل & 1 & (مدير الإدارة) \\
\hline 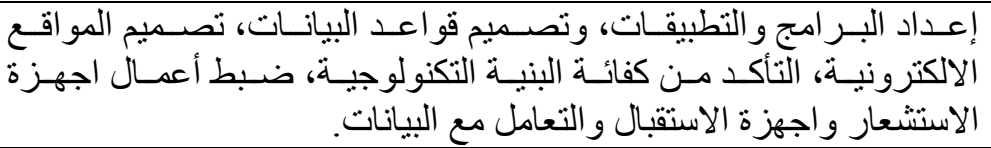 & 2 & مبرمج \\
\hline 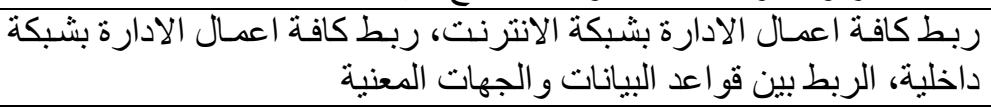 & 2 & 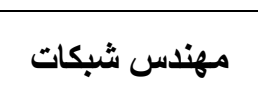 \\
\hline 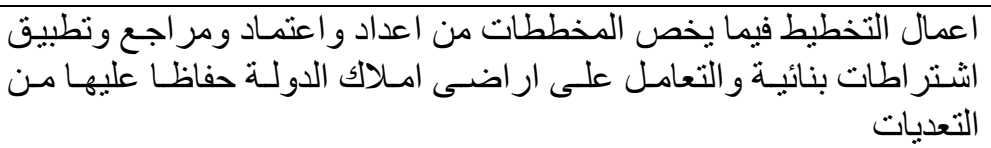 & 4 & مهندس تخطيط \\
\hline المشاركة فى اللجان المختلفة الخاصة بالتراث و المشرو عات & 4 & مهندس معمارى \\
\hline 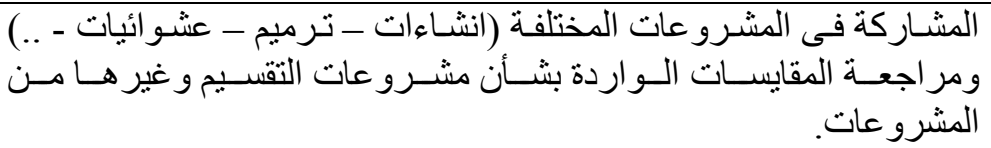 & 4 & \\
\hline أعمال توصيل الكهرباء للمشروعات المختلفة & 2 & مهندس كهرباء \\
\hline 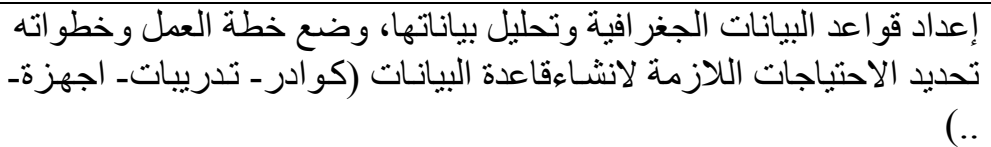 & 2 & معلومات جغرافئم نظمة \\
\hline 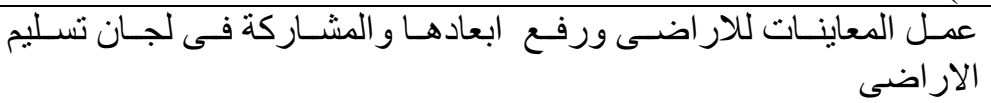 & 10 & فنى مساحة \\
\hline الاعمال الادارية وشئون العاملين بالادارة وميكنة اعمال الادارة & 10 & 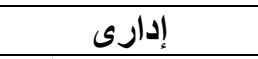 \\
\hline فى اعمال التتمية و الترويج لأهمية ذللك. & 2 & علاقات علامة \\
\hline إنجاز الأعمال المكتبية وتنظيم المو اعيد و غيرها & 3 & سكرتارية إدارية \\
\hline تنظيم التنريب و المتابعة و التقييم & 4 & مسئول متابعة \\
\hline المساعدات اللوجسنية المختلفة & 2 & 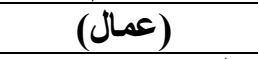 \\
\hline
\end{tabular}

شكل رقم (8) الأنظمة والتطبيقات وقو اعد بيانات أعمال الإدارة

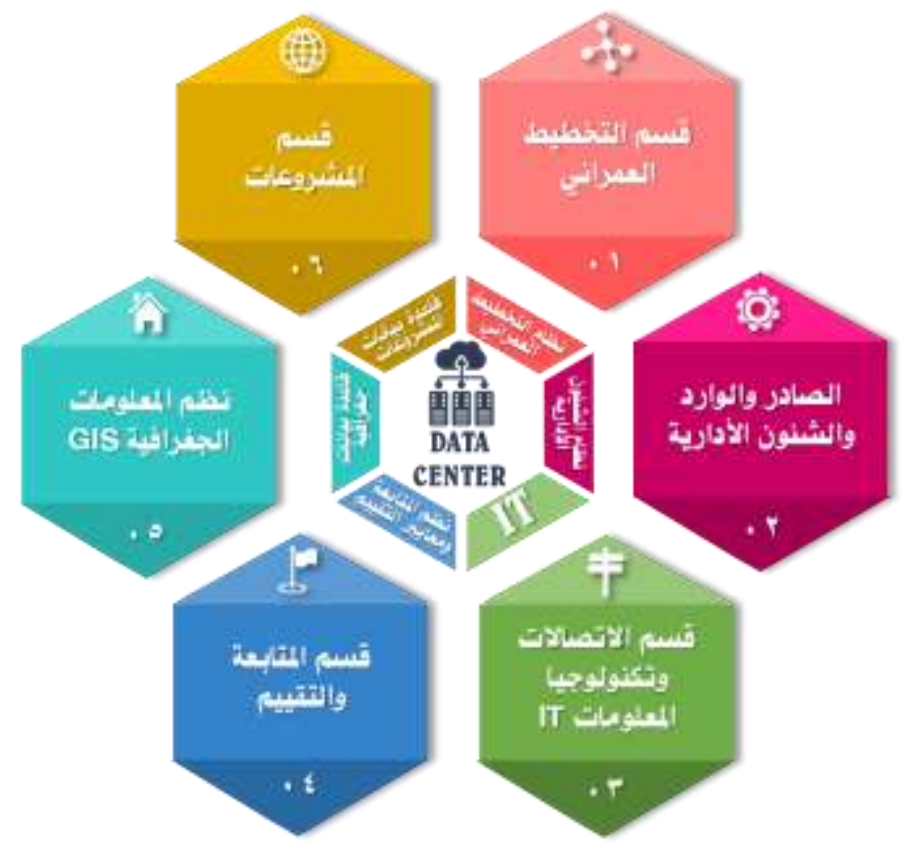

19 AA 
4-2-3 المخرجات والأنشطة المقترحة

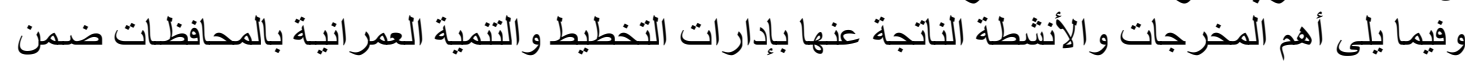
خطة التحول الرقمى و الإدارة الأكية.

جدول رقم (5) المخرجات والأنثطة المقترحة لإدارات التخطيط والتنمية العمر انية بالمحافظات ضمن خطة التمبة

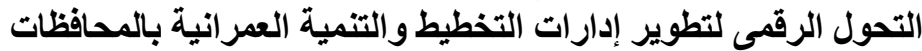

\begin{tabular}{|c|c|c|}
\hline 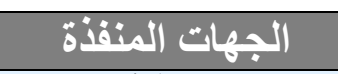 & الأشططة & المخرجات \\
\hline \multicolumn{3}{|c|}{ (هدف) إعادة هيكلة إدارة التخطيط والتنمية العمرانية بالسويس بنسبة880\% خلال ستة أشهر } \\
\hline \multirow{6}{*}{ 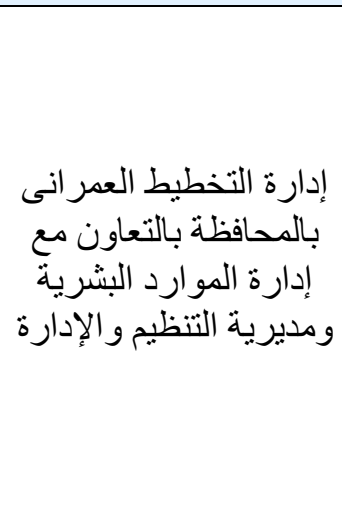 } & تحدديد الرؤية ـ الرسالة _ الهذف & \multirow{5}{*}{ 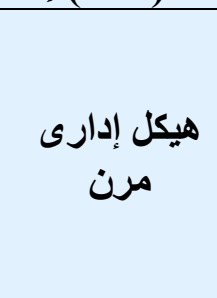 } \\
\hline & إعادة ترتيب أعمال الإدارة و أقسامها استحداث قسم المتابعة & \\
\hline & و التقييم وقسم الأتصالات وتكنولوجيا المعلومات & \\
\hline & وضع تصور للإستفادة من مؤدى الخدمة العامة من خريجى & \\
\hline & 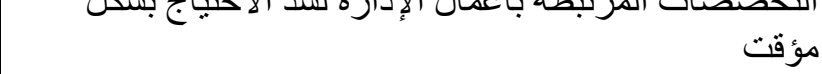 & \\
\hline & تحديد الإحتياجات من العمالة (أعداد - تخصصات - خبر ات & 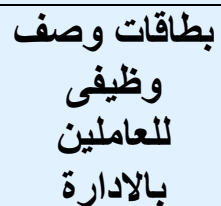 \\
\hline \multirow{4}{*}{ 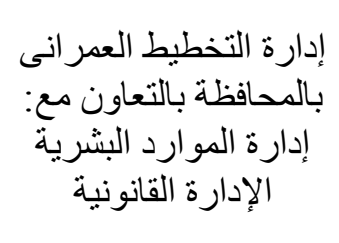 } & تحديد مسار ات العمل داخل الإدارة & \multirow{4}{*}{ لائحة تنفيذية } \\
\hline & تحديد علاقة الإدارة مع الإدار ات و الجهات الأخرى & \\
\hline & تحديد آليات المتابعة و التقبيم & \\
\hline & 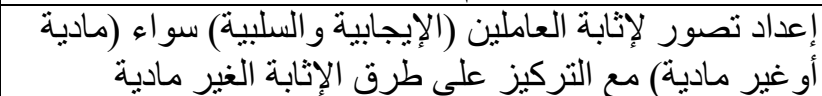 & \\
\hline \multirow{4}{*}{ إدارة التخطيط العمر انى } & 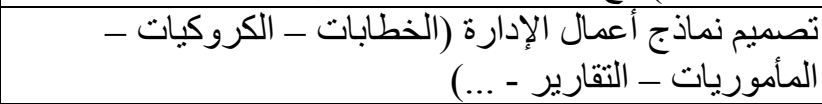 & \multirow{4}{*}{ ولتظومة } \\
\hline & متابعة تطبيق وتحديث خطة العمل بالإدارة & \\
\hline & تحديد معايير تقييم اداء الادارة و العاملين بها (عمل KPIs) & \\
\hline & عرض تقارير دورية ومقترحات رفع كفاءة أداء الإدارة & \\
\hline خلال ستة أشهر & \multicolumn{2}{|c|}{ (هدف) تنمية مهارات العاملين بالإدارة كلا فى مجاله بنسبة 70\% } \\
\hline \multirow{8}{*}{ 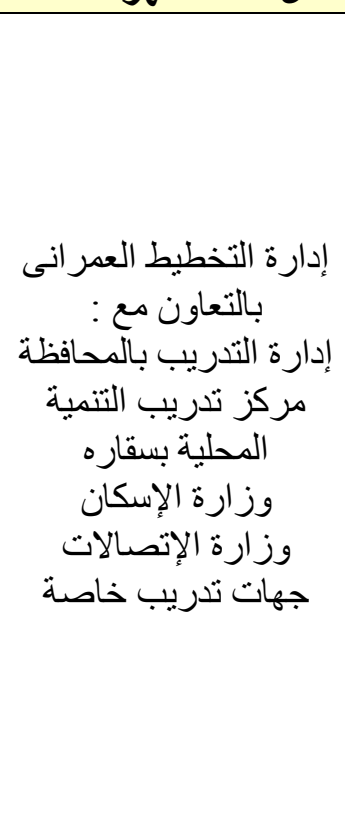 } & 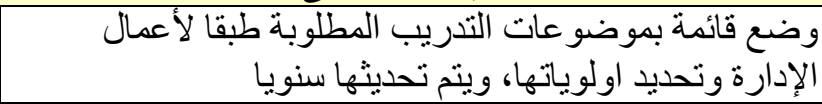 & \multirow{4}{*}{ خطة تلاريبية } \\
\hline & 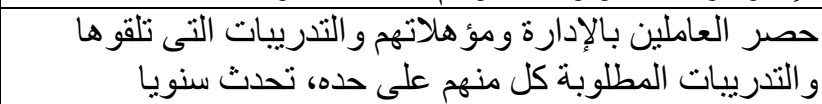 & \\
\hline & وأماكنه وتوفير إدارة الإعتماديب بالديو المانية العام بشأن مواعيد التدريب & \\
\hline & قائمة جهات المدربين وجهات التدريب بعد كل دورة تدريبية لتحديث & \\
\hline & المعراد إختبار ات الإحتياج الفعليم قبل وتحديد التنديب القبول لتحديد مستوى للتحصيل & \\
\hline & التدريب التى حصلى إنوار عليها للعاملين بالإدارة فى موضو عات & \\
\hline & 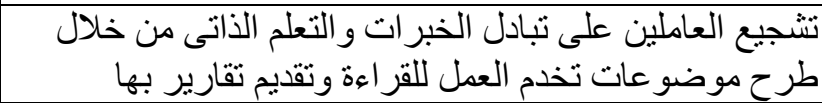 & \\
\hline & 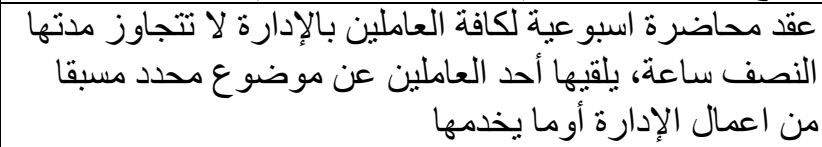 & \\
\hline
\end{tabular}




\begin{tabular}{|c|c|c|}
\hline البجهات المنمذّة & الأشמطة & \\
\hline & \multicolumn{2}{|c|}{ (هدف) تطوير البنية التكنولوجية والمعلوماتية للإدارة بنسبة 60\% } \\
\hline \multirow{10}{*}{ 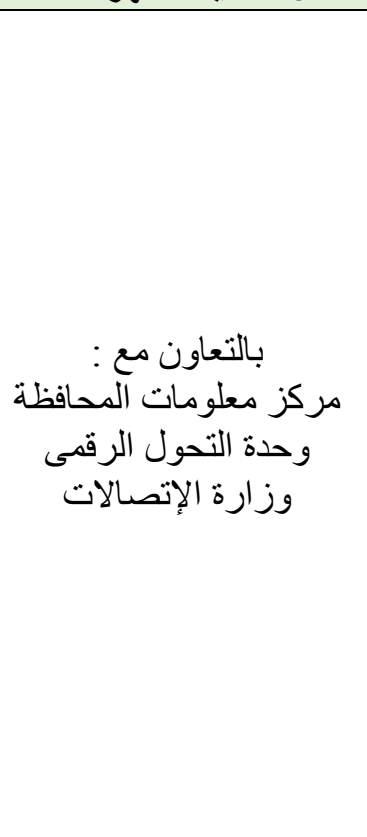 } & ربط الإدارة بالكامل بشبكة داخلية، وتوصيلها بشبكة انترنت & \multirow{10}{*}{ الداعدة بيانات العمال } \\
\hline & تصميم قاعدة البيانات باستخدام احد البرمجيات المتخصصة & \\
\hline & (مثال : جافا، .. ) تحتوى كافة اعمال الادارة وبيانات موظفيها & \\
\hline & و الخطة التدرييية ومعدلات الاداء. & \\
\hline & أرشفة الكترونية لكل ملفات ومكاتبات الإدارة. & \\
\hline & تصميم تطبيق لتوزيع ومتابعة المهام مربوط بقاعدة البيانات & \\
\hline & 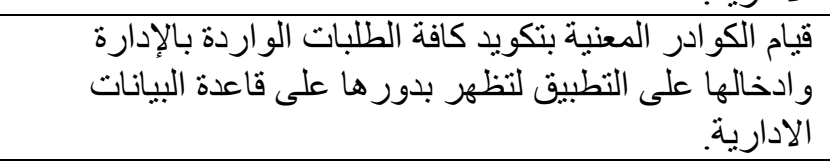 & \\
\hline & 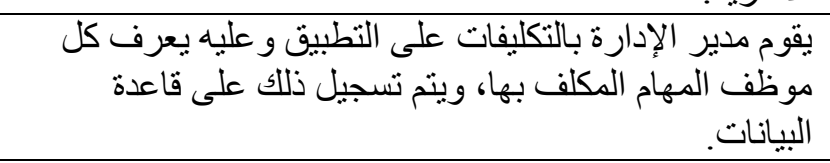 & \\
\hline & الذقى قام به مسجلا بالتاريخ. & \\
\hline & قيمدة البياناتة الإدارية. & \\
\hline 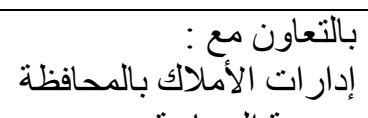 & 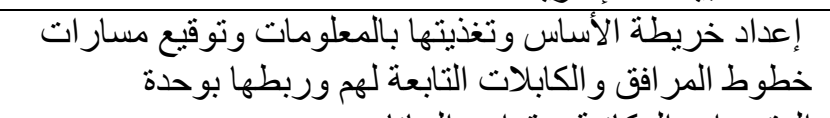 & 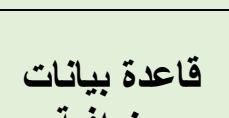 \\
\hline مديرية المساحة & المتغيرات المكانبة وقو اعد البيانات. & 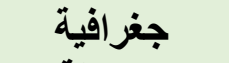 \\
\hline وحدة إدارة التخطيط العمر انتى التمية المحلية & اعداد الخر ائط الاستثمارية و السياحية للمحافظة. & للمحافظة متلة \\
\hline 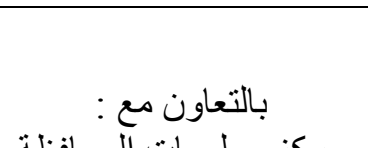 & 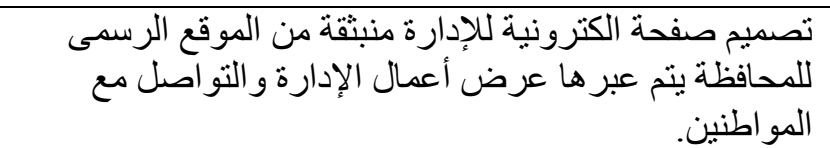 & صفحة للادارة \\
\hline وز مز معلومات المحافظه & 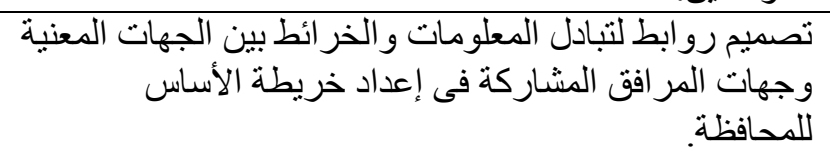 & للمحافظة \\
\hline إدارة الأزمات بالمحافظة & 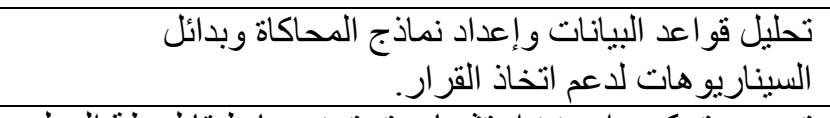 & منظومة رصليل \\
\hline وحدة الـ GIS بوزارة & توبشكل مرتركيّ. اجهزة استشعار يتم توزيعها طبقا لخطة العمل & 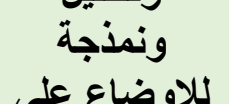 \\
\hline & التواصل المستمر و المباشر مع الأوضاع على الطبيعة. & \\
\hline & (هدف) التحول لإدارة ذكية للعمران بنسبة 20\% & \\
\hline مركز معلومات المحافظة & الخدمية بشَكل مستمر . التنات المر افق و الجهات الامنية و المديريات & \\
\hline شركات المر افق المختلفة & طرح بعض طبيقات الهاتف بمعلومات وخر ائط عن المدينة. & في إدار \\
\hline الهيئة العامة للتخطيط العمر انى & الالكترونية. & 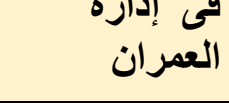 \\
\hline 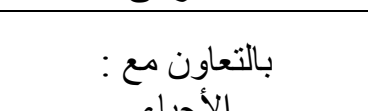 & 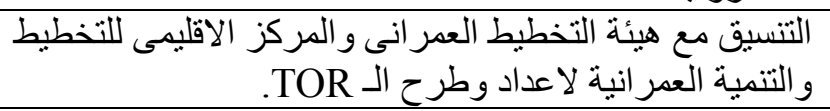 & \\
\hline مركز إقليمى للتخطيط الاحياء & باعداد المخططات مع استشارى ذوخبلةه (اختيارى) / قيام كو ادر الادارة & تفصطيلية \\
\hline & تطبيق المخططة واعناد المخططات الطيعة. & \\
\hline
\end{tabular}


شكل رقم (9) منظومة التحول الرقمى لإدارة التخطيط العمرانى

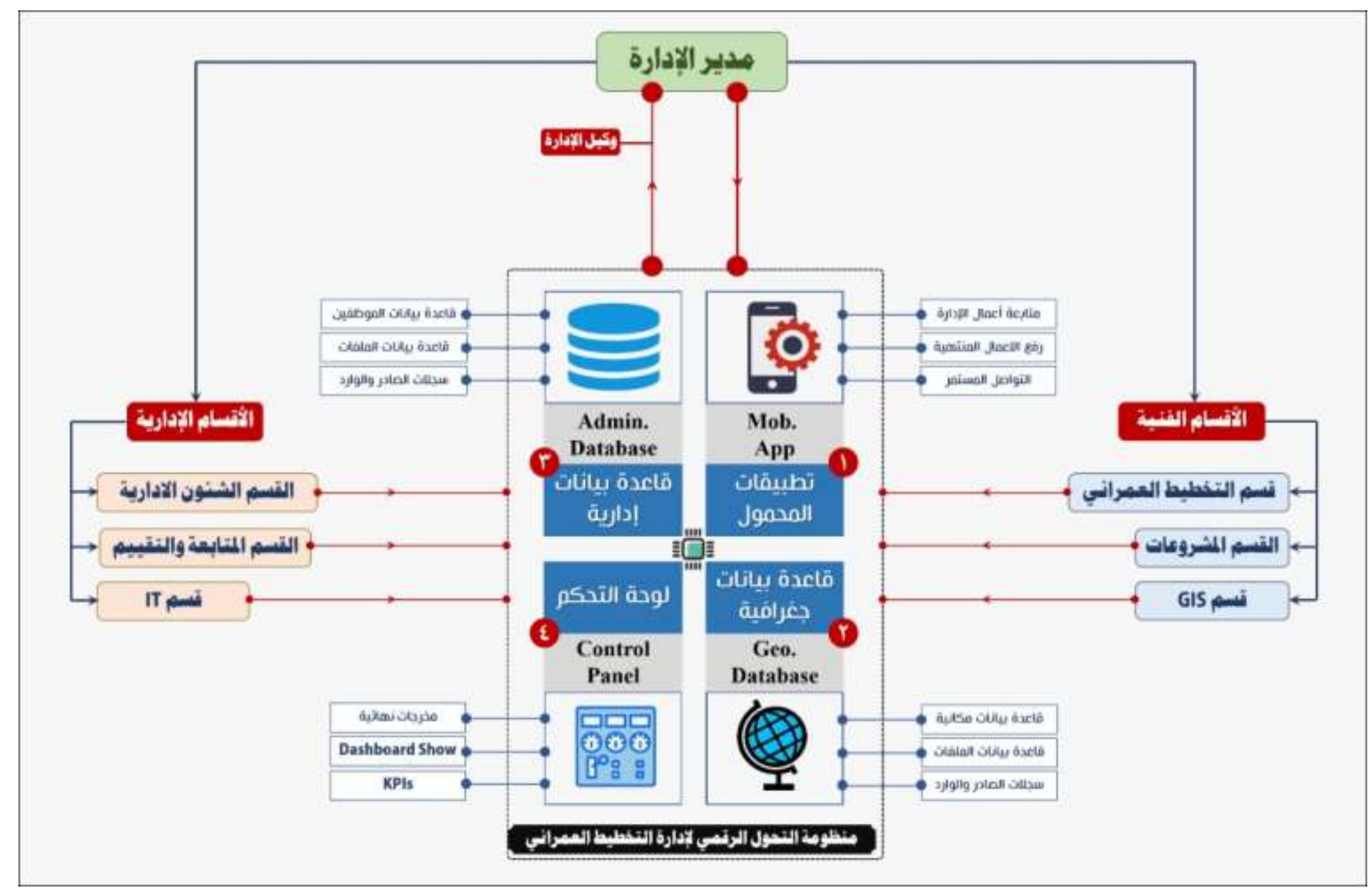




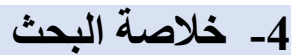

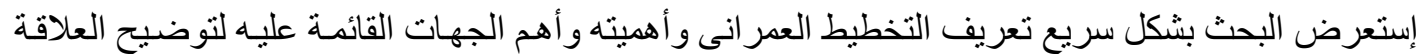

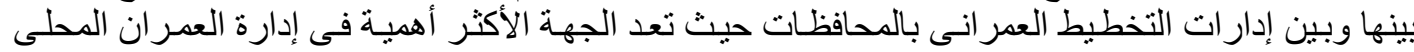

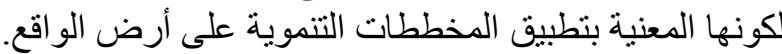

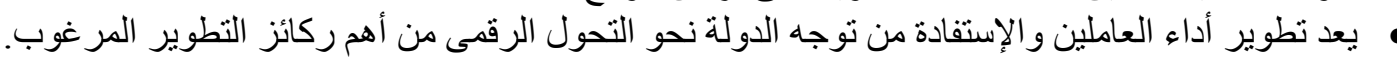

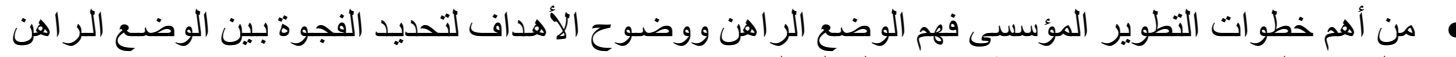

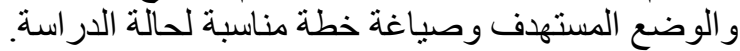

تم صياغة أهداف ذكية محددة وقابلة للقياس ، وتحديد الأنشطة اللازمة لتحقيقها وذللك لضمان إمكانية المتابعة و التقبيج.

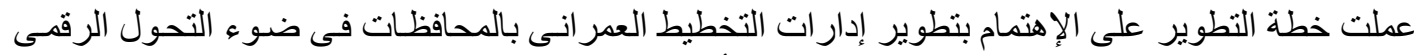

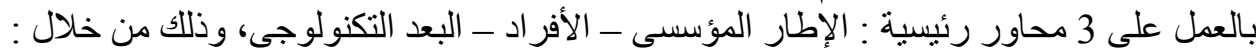

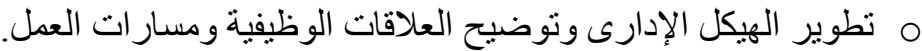

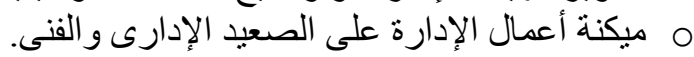

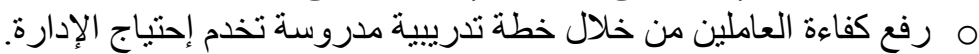

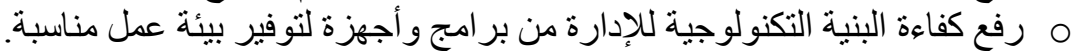

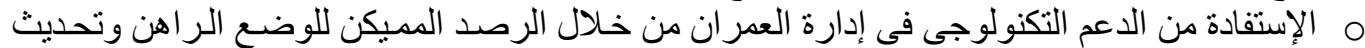

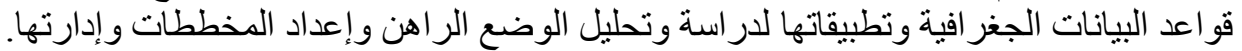

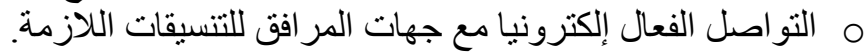

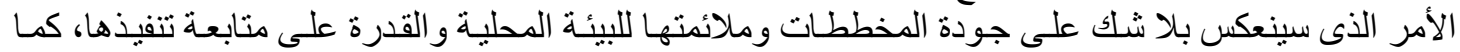

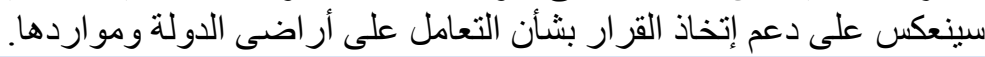

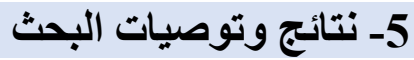
1-5 1-5 نتائج البحت وتوصيات

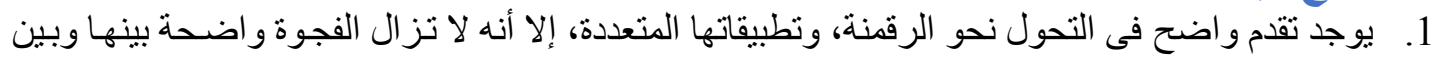

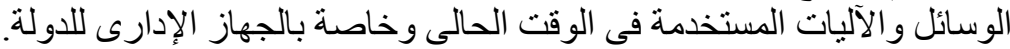

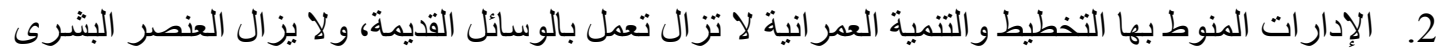

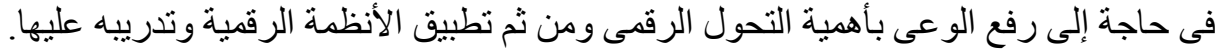

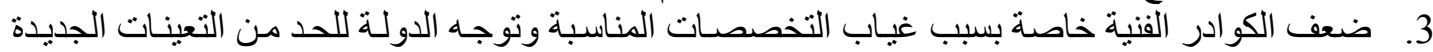
و التعاقد بنظام عقود الإستضافة وعزوف الفادة التخصصات المطلوبة عن التقام.

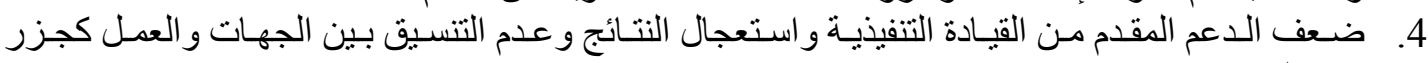
منفصلة.

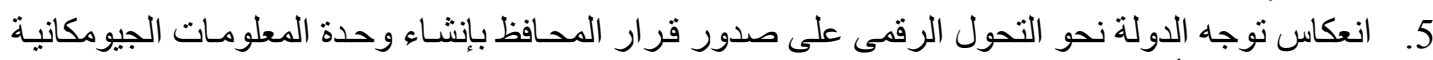
ضمن أقسام إدارة التخطيط و التتمية العمر انية لإعداد وتحديث قوار العد البيانات الجغر افية للمحافظة.

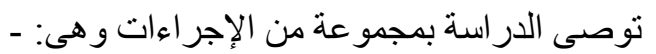

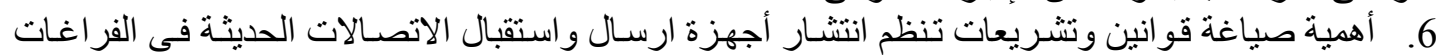

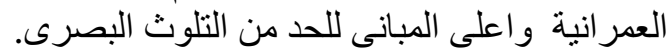

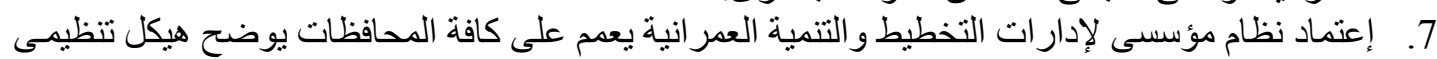

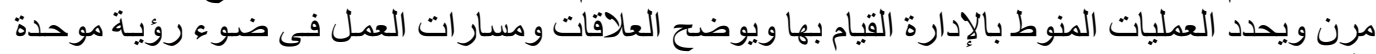

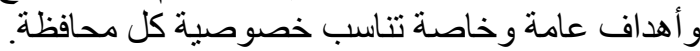
8. تحديد التخصصات المطلوبة و الخبر ات اللازمة للعمل فى إدار ات التخطيط وات التنمية العمر انية بالمحافظات

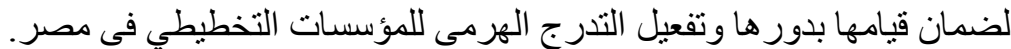

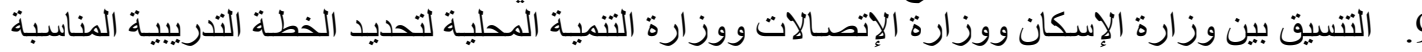

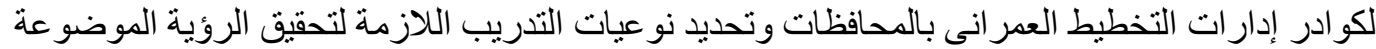

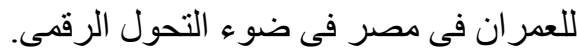

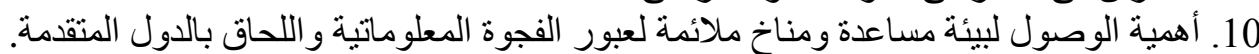

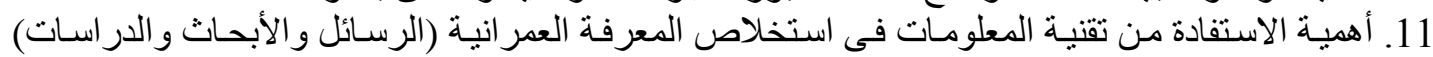
و إعادة هيكلتها وتنظيمها و الاستفادة منها وتطبيقها في في التنمية العمر انية. 


\section{المراجع العربية المبية}

الأمم المتحدة 2019 ـ الإبتكـار والتكنولوجيا من أجل التنمية المستدامة آفاق واعدة في المنطقة العربية لعـام arab-horizon-2030-innovation-perspectives-sdgs-arab-region-arabic.pdf $\mathbf{- 2 0 3 0}$

2. القاضي، أحمد نجيب، خصائص المدن الأكية ودورها فى التحول الى استدامة المدينة المصرية ، المجلة

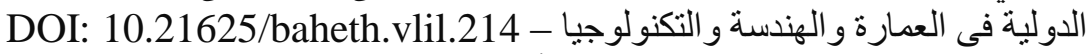

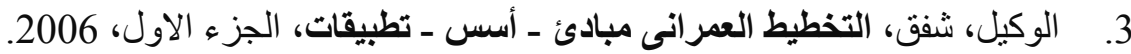

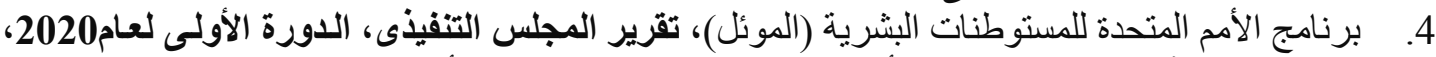

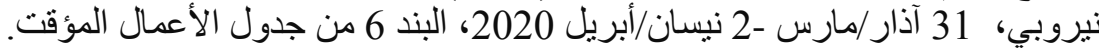

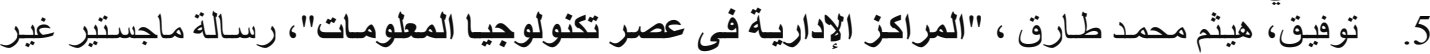
منشورة، كلية الهندسة، جامعة مئمة القاهرة،

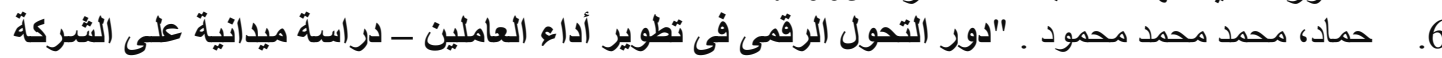

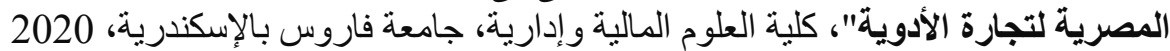
7. و التكنولوجيا، (2014).

8. شاهين، شريف، "الشهادة العربية للثقافة المعلوماتية : ضرورة ملحة لنجـاح مجتمعات المعرفة"، ورقة

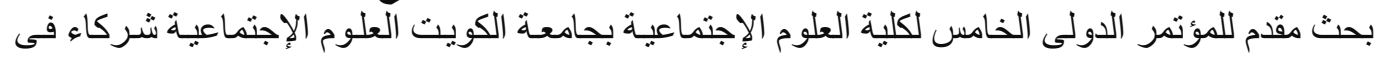

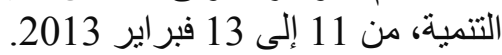

9. ندا، محمد شكر، مجدى، شئهاء أحمد، بدوى، عبد الله، التحول الرقمى للعمر ان مدخل للتعامـل مـع العمران

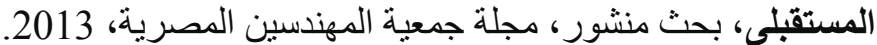

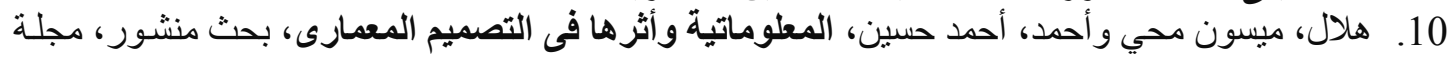

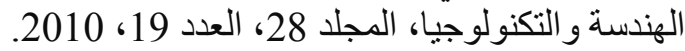

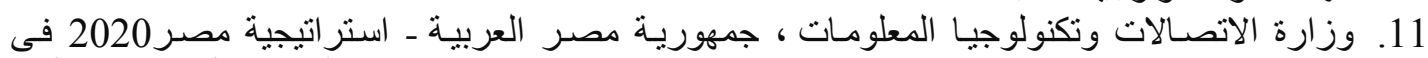

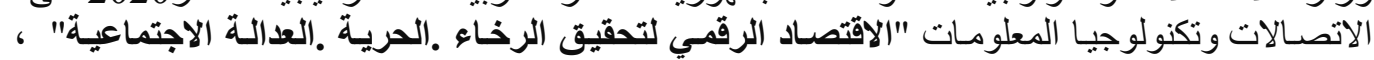

العرض التقدمي للوزير ، 2015

\section{المراجع الأجنبية}

1. Aoun, Ch., The Smart City Cornerstone: Urban Efficiency, Schneider Electric, smart cities white paper (April), 2013.

2. David, Thomas, Enterprise architectures for the digital transformation in small and medium-sized enterprises, 11th CIRP Conference on Intelligent Computation in Manufacturing Engineering - CIRP ICME '17, 2018.

3. Ivarsson, Frida (2020), Digital and Conventional Matchmaking Similarities, Differences and Tensions, Proceedings of the 53rd Hawaii International Conference on System Sciences

4. Mitchell, A., The ESRI Guide to Smart Analysis - Geographic Patterns and Relationships", ESRI press, NY, USAM 2007.

5. Schmidt, F, "Increased accuracy of rang restriction correction: implementations for the role of personality and general mental ability in job and training performance", Personnel Psychology. 2010.

6. Yigitcanlar,T., Knowledge-Based Urban Development: Planning and Applications in the Information Era, Information Science Reference ( IGI Global) ,Hershey , New York, 2012.

7. Ziyadin, Suieubayeva, Digital Transformation in Business, Springer Nature Switzerland AG 2020, LNNS 84, pp. 408-415.

8. https://www.arab-api.org/images/training/programs/1/2016/359_P16020-2.pdf

9. https://www.facebook.com/399653700076341/posts/1277242065650829/

10. https://www.netsuite.com/portal/resource/articles/erp/what-is-erp.shtml

11. https://unearthlabs.com/blog/gis-uses/urban-planning/ 